\title{
Challenges associated with the climatic interpretation of water stable isotope records from a highly resolved firn core from Adélie Land, coastal Antarctica
}

\author{
Sentia Goursaud ${ }^{1,2}$, Valérie Masson-Delmotte ${ }^{1}$, Vincent Favier $^{2}$, Suzanne Preunkert $^{2}$, Michel Legrand ${ }^{2}$, \\ Bénédicte Minster ${ }^{1}$, and Martin Werner ${ }^{3}$ \\ ${ }^{1}$ LSCE (UMR CEA-CNRS-UVSQ 8212-IPSL), Gif-sur-Yvette, France \\ ${ }^{2}$ Univ. Grenoble Alpes, CNRS, IGE, 38000 Grenoble, France \\ ${ }^{3}$ Alfred Wegener Institute, Helmholtz Centre for Polar and Marine Research, Bremerhaven, Germany
}

Correspondence: Sentia Goursaud (sentia.goursaud@1sce.ipsl.fr)

Received: 7 June 2018 - Discussion started: 4 July 2018

Revised: 12 March 2019 - Accepted: 14 March 2019 - Published: 24 April 2019

\begin{abstract}
A new $21.3 \mathrm{~m}$ firn core was drilled in 2015 at a coastal Antarctic high-accumulation site in Adélie Land (66.78 $\mathrm{S} ; 139.56^{\circ} \mathrm{E}, 602 \mathrm{~m}$ a.s.1.), named Terre Adélie 192A (TA192A).

The mean isotopic values $\left(-19.3 \% \circ \pm 3.1 \%\right.$ for $\delta^{18} \mathrm{O}$ and $5.4 \% \circ \pm 2.2 \%$ for deuterium excess) are consistent with other coastal Antarctic values. No significant isotope-temperature relationship can be evidenced at any timescale. This rules out a simple interpretation in terms of local temperature. An observed asymmetry in the $\delta^{18} \mathrm{O}$ seasonal cycle may be explained by the precipitation of air masses coming from the eastern and western sectors in autumn and winter, recorded in the $d$-excess signal showing outstanding values in austral spring versus autumn. Significant positive trends are observed in the annual $d$-excess record and local sea ice extent (135-145 ${ }^{\circ}$ E) over the period 1998-2014.

However, process studies focusing on resulting isotopic compositions and particularly the deuterium excess $-\delta^{18} \mathrm{O}$ relationship, evidenced as a potential fingerprint of moisture origins, as well as the collection of more isotopic measurements in Adélie Land are needed for an accurate interpretation of our signals.
\end{abstract}

\section{Introduction}

\subsection{Motivation for new coastal Antarctic firn cores}

Polar ice cores are exceptional archives of past climate variations. In Antarctica, many deep ice cores have been drilled and analysed since the 1950s. For instance, Stenni et al. (2017) compiled water stable isotope data from 112 ice cores spanning at least part of the last 2000 years. Most deep ice cores were drilled in the central Antarctic plateau where low accumulation rates and ice thinning give access to long climate records. In today's context of rapid global climate change, it is of paramount importance to also document recent past climate variability around Antarctica. Many Antarctic regions still remain undocumented due to the lack of accumulation and water stable isotope records from shallow ice cores or pits (Jones et al., 2016; Masson-Delmotte et al., 2008). An accurate knowledge of changes in coastal Antarctic surface mass balance (SMB), an evaluation of the ability of climate models to resolve the key processes affecting its variability, and thus an improved confidence in projections of future changes in coastal Antarctic surface mass balance are important to reduce uncertainties on the ice sheet mass balance and its contribution to sea level change (Church et al., 2013).

Meteorological observations have been conducted since 1957 in manned and automatic stations (Nicolas and Bromwich, 2014), and considerable efforts have been deployed to compile and update the corresponding dataset 
(Turner et al., 2004). This network is marked by gaps in spatio-temporal coverage (Goursaud et al., 2017) as well as systematic biases of instruments such as thermistors (Genthon et al., 2011). Satellite remote-sensing data have been available since 1979 and provide large-scale information for changes in Antarctic sea ice and temperature (Comiso et al., 2017), but do not provide sufficient accuracy and homogeneity to resolve trends at local scales (Bouchard et al., 2010). Coastal shallow (20-50 m long) firn cores are thus essential to provide continuous climate information spanning the last decades at sub-annual resolution, at local but also regional scales. They complement stake area observations of spatiotemporal variability in surface mass balance (Favier et al., 2013), which also help assess the representativeness of a single record.

Since the 1990s, efforts have been made to retrieve shallow ice cores in coastal Antarctic areas. Most of these efforts have been focused on the Atlantic sector, in Dronning Maud Land (Altnau et al., 2015; Graf et al., 2002; e.g. Isaksson and Karlén, 1994) and the Weddell Sea sector (Mulvaney et al., 2002). Fewer annually resolved water stable isotope records have been obtained from ice cores in other regions, such as the peninsula (Fernandoy et al., 2018), the Ross Sea sector (Bertler et al., 2011), Law Dome (Masson-Delmotte et al., 2003; Delmotte et al., 2000; Morgan et al., 1997), Adélie Land (Yao et al., 1990; Ciais et al., 1995; Goursaud et al., 2017), and the Princess Elizabeth region (Ekaykin et al., 2017). However, the recent 2000-year temperature and SMB reconstructions for the Antarctic (Stenni et al., 2017; Thomas et al., 2017) highlighted the need for more coastal records. In this line, new drilling efforts have recently been initiated in the context of the ASUMA project (Improving the Accuracy of SUrface Mass balance of Antarctica) from the French Agence Nationale de la Recherche, which aims to assess spatio-temporal variability and change in SMB over the transition zone from coastal Adélie Land to the central East Antarctic Plateau (towards Dome C).

\subsection{Climatic interpretation of water stable isotope records}

Water stable isotope $\left(\delta^{18} \mathrm{O}, \delta \mathrm{D}\right)$ records from central Antarctic ice cores have classically been used to infer past temperature changes (e.g. Jouzel et al., 1987). The isotopetemperature relationship was nevertheless shown not to be stationary and to vary in space (Jouzel et al., 1997), calling for site-specific calibrations relevant for various timescales (Stenni et al., 2017). In coastal regions, several studies showed no temporal isotope-temperature relationship at all between water stable isotope records in firn cores covering the last decades and near-surface air temperature measured at the closest station. This is for instance the case in Dronning Maud Land, near the Neumayer station (three firn cores, for which the longest covered period is 1958-2012; Vega et al., 2016), in the Ross Sea sector (one snow pit covering the period 1964-2000; Bertler et al., 2011), and in Adélie Land, close to Dumont d'Urville (DDU, one firn core covering the period 1946-2006; Goursaud et al., 2017). While several three-dimensional atmospheric modelling studies have suggested a dominant role of large-scale atmospheric circulation in the variability of coastal Antarctic snow $\delta^{18} \mathrm{O}$ (e.g. Noone, 2008; Noone and Simmonds, 2002), understanding the drivers of coastal Antarctic $\delta^{18} \mathrm{O}$ variability remains challenging (e.g. Fernandoy et al., 2018; Bertler et al., 2018; Schlosser et al., 2004; Dittmann et al., 2016). While distillation processes are expected theoretically to relate condensation temperature with precipitation isotopic composition, a number of deposition processes can distort this relationship: changes in moisture sources (Stenni et al., 2016), intermittency or seasonality of precipitation (Sime et al., 2008), boundary layer processes affecting the links between condensation and surface air temperature (Krinner et al., 2008), and several post-deposition processes, such as the effects of winds (Eisen et al., 2008), snow-air exchanges (Casado et al., 2016; Ritter et al., 2016), and diffusion processes in snow and ice (e.g. Johnsen, 1977). Nevertheless, all these processes remain poorly quantified. As a result, comparisons between firn core records with precipitation records or simulations have to be performed carefully.

Changes in the atmospheric water cycle can also be investigated using a second-order parameter, deuterium excess ( $d$-excess). The definition given by Dansgaard (1964) as $d$ excess $=\delta \mathrm{D}-8 \times \delta^{18} \mathrm{O}$ aims to remove the effect of equilibrium fractionation processes to identify differences in kinetic fractionation between the isotopes of hydrogen and oxygen. In Antarctica, spatial variations in $d$-excess have been documented through data syntheses, showing an increase from the coast to the plateau (Masson-Delmotte et al., 2008; Touzeau et al., 2016), but temporal variations in $d$-excess (seasonal cycle, inter-annual variations) remain poorly documented and understood.

Theoretical isotopic modelling studies show that $d$-excess depends on evaporation conditions, mainly through the impacts of relative humidity $(\mathrm{RH})$ and sea surface temperature (SST) on kinetic fractionation at the moisture source (Merlivat and Jouzel, 1979; Petit et al., 1991; Ciais et al., 1995), and the preservation of the initial vapour signal during transportation towards polar regions (e.g. Jouzel et al., 2013; Bonne et al., 2015). The effect of wind speed on kinetic fractionation is secondary and thus has been neglected in climatic interpretations of $d$-excess. Some studies usually privileged one variable (RH or SST). For instance, glacial-interglacial $d$ excess has classically been interpreted to reflect past changes in moisture source SST, neglecting RH effects or assuming co-variations in RH and SST (Vimeux et al., 2001, 1999; Stenni et al., 2001). Recent measurements of $d$-excess in water vapour from ships have evidenced a close relationship between $d$-excess and oceanic surface conditions, especially RH, at sub-monthly scales (Pfahl and Sodemann, 2014; Uemura et al., 2008; Kurita et al., 2016). Other recent studies 
have suggested that evaporation at sea ice margins may be associated with a high $d$-excess value due to low RH effects, a process which may not be well captured in atmospheric general circulation models (e.g. Kurita, GRL, 2011; SteenLarsen et al., 2017). Several authors have thus identified the potential to identify changes in moisture sources using $d$ excess (Delmotte et al., 2000; Sodemann and Stohl, 2009; Ciais et al., 1995). The comparison between multi-year isotopic precipitation datasets with the identification of air mass origins using back trajectories showed, however, a complex picture, with no trivial relationship between the latitudinal air mass origin and $d$-excess (Dittmann et al., 2016; Schlosser et al., 2008). A few studies have also explored sub-annual $d$ excess variations and suggested that seasonal $d$-excess signals cannot be explained without accounting for seasonal changes in moisture transport (e.g. Delmotte et al., 2000). These features have been explored through the identification of back-trajectory clusters and their relationship with $\delta^{18} \mathrm{O}-$ $d$-excess relationships, including phase lags (Markle et al., 2012; Caiazzo et al., 2016; Schlosser et al., 2017).

Most of these $d$-excess studies have been performed using firn records and not precipitation samples. We stress that the impact of post-deposition processes on $d$-excess remain poorly documented and understood. While relationships between moisture origin and $d$-excess should in principle be conducted on vapour measurements to circumvent the uncertainties associated with deposition and post-deposition processes, the available vapour water stable isotope records from Antarctica only cover 1 or 2 summer months (Ritter et al., 2016; Casado et al., 2016) and do not yet allow exploration of the relationships between moisture transport and seasonal or inter-annual isotopic variations. Also, state-of-the-art atmospheric general circulation models equipped with water stable isotopes such as ECHAM5-wiso can capture $d$-excess spatial patterns in Antarctic snow, but they fail to correctly reproduce its seasonal variations (Goursaud et al., 2017). Finally, the understanding of the climatic signals preserved in $d$-excess is limited by the available observations. This motivates the importance of retrieval of more highly resolved $d$-excess records from coastal Antarctic firn cores.

\subsection{This study}

In this study, we focus on the first highly resolved firn core drilled in coastal Adélie Land, at the TA192A site $\left(66.78^{\circ} \mathrm{S}\right.$, $139.56^{\circ} \mathrm{E}$; $602 \mathrm{~m}$ a.s.1., hereafter named TA). Only two ice cores and one snow pit were previously studied for water stable isotopes in this region, without any $d$-excess record: the S1C1 ice core (14 km from the TA, 279 ma.s.l.; Goursaud et al., 2017), the D47 highly resolved pit (78 km from the TA, $1550 \mathrm{~m}$ a.s.l.; Ciais et al., 1995), and the Caroline ice core (Yao et al., 1990). The climate of coastal Adélie Land is greatly influenced by katabatic winds (resulting in a very high spatial variability of accumulation) and by the presence of sea ice (Périard and Pettré, 1993; König-Langlo et al., 1998), including the episodic formation of winter polynya (Adolphs and Wendler, 1995), which lead to nearby open water during wintertime. The regional climate has been well documented since March 1957 at the meteorological station of Dumont d'Urville, where multi-year atmospheric aerosol monitoring has also been performed (e.g. Jourdain and Legrand, 2001). The spatio-temporal variability of regional SMB has also been monitored at an annual timescale since 2004 through stake height and snow density measurement over a $156 \mathrm{~km}$ stake line (91 stakes) (Agosta et al., 2012; Favier et al., 2013). The TA firn core was analysed at sub-annual resolution for water isotopes $\left(\delta^{18} \mathrm{O}\right.$ and $\left.\delta \mathrm{D}\right)$ and chemistry ( $\mathrm{Na}, \mathrm{SO}_{4}^{2-}$, and methane sulfonate, MSA). These records were used to establish the age scale for the firn core. Using these records, we explore (i) the links between the TA isotopic signals, local climate, and atmospheric transport, (ii) the possibility to extract a sub-annual signal from such a highly resolved core, and (iii) how to interpret the $d$-excess signal of coastal Antarctic ice cores.

In this paper, we first present our material and methods (Sect. 2), then describe our results (Sect. 3) and compare them with other Antarctic records and the outputs of the ECHAM5-wiso model in our discussion (Sect. 4), before summarizing our key findings and formulating suggestions for future studies (Sect. 5).

\section{Materials and methods}

\subsection{Field work and laboratory analyses}

Here we present the results of one firn core drilled at the TA site $\left(66.78,139.56^{\circ} \mathrm{S} ; 602 \mathrm{~m}\right.$ a.s.1.), located at $25 \mathrm{~km}$ from the Dumont d'Urville station (DDU) and at $14 \mathrm{~km}$ from the S1C1 ice core (Goursaud et al., 2017; Fig. 1). The $21.3 \mathrm{~m}$ long firn core was drilled on 29 January 2015, when the daily surface air temperature and wind speed were $-8.5^{\circ} \mathrm{C}$ and $3.9 \mathrm{~m} \mathrm{~s}^{-1}$ respectively at the D17 station $(9 \mathrm{~km}$ from the drilling site).

The FELICS (Fast Electrochemical lightweight Ice Coring System) drill system was used (Ginot et al., 2002; Verfaillie et al., 2012). Firn core pieces were then sealed in polyethylene bags, stapled, and stored in clean isothermal boxes. At the end of the field campaign, the boxes were transported in a frozen state to the cold-room facilities of the Institute of Environmental Geoscience (IGE, Grenoble, France). Every core piece was weighted and its length measured in order to produce a density profile. The cores were sampled at $4 \mathrm{~cm}$ resolution, leading to a total of 533 samples for oxygen isotopic ratio and ionic concentrations following the method described in Goursaud et al. (2017). Samples devoted to ionic concentration measurements were stored in the cold room until concentrations of sodium $\left(\mathrm{Na}^{+}\right)$, sulfate $\left(\mathrm{SO}_{4}^{2-}\right)$, and methane sulfonate (MSA) were analysed by ion chromatography equipped with a CS12 and an AS11 separator col- 


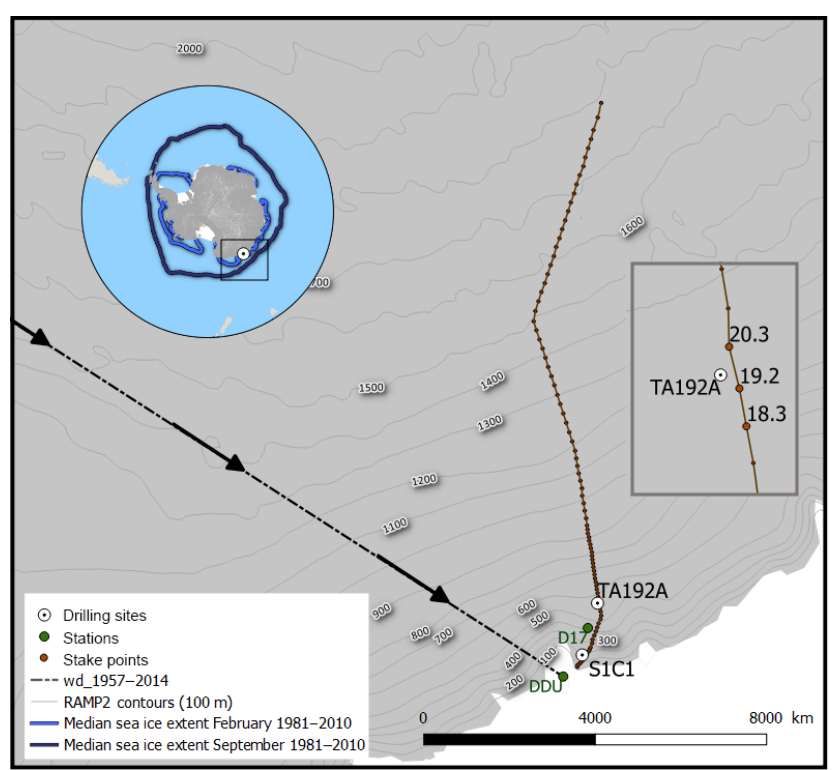

Figure 1. Map showing the location of the drilling sites of the S1C1 and TA192A firn cores (black points), the Dumont d'Urville and D17 stations (green points), the stake points (in brown; included the three closest stake points from the TA192A, namely the 18.3, 19.2, and 20.3 lines, and $156 \mathrm{~km}$ stake line), and the mean wind direction over the period 1957-2014 (in black). Isohypses (grey lines) shown in the main figure are simulations from adigital elevation model, large-scale resolution. Radarsat Antarctic Mapping Project Digital Elevation Model version 2 (Liu et al., 2001). The map of Antarctica on the top left displays the mean February and September sea ice extent over the period 1981-2010 extracted from the Nimbus-7 Scanning Multichannel Microwave Radiometer (SMMR) and Defense Meteorological Satellite Program Special Sensor Microwave/Imagers - Special Sensor Microwave Image/Sounder (DMSP SSM/I-SSMIS) passive microwave data (http: //nsidc.org/data/nsidc-0051, last access: January 2018) (Cavalieri et al., 1996) (light blue and dark blue lines respectively), and the zoomed area (grey rectangle), while the grey rectangle in the middle right zooms the area around the TA192A drilling site in order to show the three closest stake locations.

umn, for cations and anions respectively. Samples devoted to oxygen isotopic ratio were sent to LSCE (Gif-sur-Yvette, France) and analysed following two methods. First, $\delta^{18} \mathrm{O}$ was measured by the $\mathrm{CO}_{2} / \mathrm{H}_{2} \mathrm{O}$ equilibration method on a Finnigan MAT 252, using two standards calibrated to SMOWSLAP international scales, with an accuracy of $0.05 \%$. Second, $\delta^{18} \mathrm{O}$ and $\delta \mathrm{D}$ were also measured using a laser cavity ring-down spectroscopy (CRDS) Picarro analyser, using the same standards, leading to an accuracy of $0.2 \%$ and $0.7 \%$ o for $\delta^{18} \mathrm{O}$ and $\delta \mathrm{D}$ respectively. The resulting accuracy of $d$ excess, calculated using a quadratic approach, is $1.7 \%$.

\subsection{Datasets}

\subsubsection{Instrumental data}

To assess potential climate signals archived in our firn core records, we extracted meteorological data to explore regional climate signals, and outputs of atmospheric models to explore synoptic scale climate signals. The regional climate is well documented since 1957 thanks to the continuous meteorological monitoring at DDU station (https://donneespubliques.meteofrance. fr/?fond=produit\&id_produit=90\&id_rubrique $=32$, last access: January 2018), with one gap between March 1959 and January 1960. We extracted near-surface temperature, humidity, surface pressure, wind speed and wind direction data computed monthly and annual averages over the periods 1957-2014 and 1998-2014.

The monthly average sea ice concentration was extracted from the Nimbus-7 Scanning Multichannel Microwave Radiometer (SMMR) and Defense Meteorological Satellite Program Special Sensor Microwave/Imagers - Special Sensor Microwave Image/Sounder (DMSP SSM/I-SSMIS) passive microwave data (http://nsidc.org/data/nsidc-0051, last access: January 2018), over the $50-90^{\circ} \mathrm{S}$ latitudinal range at a $25 \mathrm{~km} \times 25 \mathrm{~km}$ grid resolution (Cavalieri et al., 1996). D'Urville summer sea ice extent was estimated by extracting the number of grid points covering the area $\left(50-90^{\circ} \mathrm{S}\right.$, $135-145^{\circ} \mathrm{E}$ ) where the sea ice concentration is higher than $15 \%$, from December to January (included) for each year from 1998 to 2014.

SMB measurements from stake point data were obtained from the GLACIOCLIM observatory (https://glacioclim. osug.fr/, last access: January 2018). We extracted data from the three stakes closest to the TA drilling site, namely 18.3 $\left(66.77^{\circ} \mathrm{S}, 139.57^{\circ} \mathrm{E} ; 1.04 \mathrm{~km}\right.$ from the TA drill site), 19.2 $\left(66.77^{\circ} \mathrm{S}, 139.56^{\circ} \mathrm{E} ; 83 \mathrm{~m}\right.$ from the drilling TA site), and $20.3\left(66.78^{\circ} \mathrm{S}, 139.55^{\circ} \mathrm{E} ; 1.00 \mathrm{~km}\right.$ from the drilling TA site), all spanning the period 2004-2014.

\subsubsection{Database of surface snow isotopic composition}

In order to compare the $d$-excess record from the TA firn core with available Antarctic values, we have updated the database of Masson-Delmotte et al. (2008), by adding 26 new data points from precipitation and firn core measurements provided with $d$-excess (Table 1). This includes data from five ice cores from the database constituted by the Antarctica2k group (Stenni et al., 2017). Altogether, the updated database includes 777 locations. This includes 64 coastal sites at an elevation lower than 1000 ma.s.l., (with 19 new datasets). These data were extracted from our updated isotope database (Goursaud et al., 2018a) archived in the PANGAEA data library (https://doi.org/10.1594/PANGAEA.891279). 
Table 1. Site, latitude $\left({ }^{\circ}\right)$, longitude $\left({ }^{\circ} \mathrm{E}\right)$, and reference of new $d$-excess data added to Masson-Delmotte et al. (2008). Data in (a) correspond to precipitation, (b) data correspond to ice cores extracted from the Antarctica2k database (Stenni et al., 2017), and (c) data are new data compared to our prior database (Goursaud et al., 2017).

\begin{tabular}{|c|c|c|c|}
\hline Site & Latitude & Longitude & Reference \\
\hline \multicolumn{4}{|l|}{ (a) } \\
\hline Frei (South Shetland Islands)* & -62.20 & 301.04 & Fernandoy et al. (2012) \\
\hline O’Higgins (north peninsula)* & -63.32 & 302.10 & Fernandoy et al. (2012) \\
\hline Halley & -75.58 & 333.50 & Rozanski et al. (1993) \\
\hline Base tte. Marsh & -62.12 & 301.44 & Rozanski et al. (1993) \\
\hline Rothera Point & -67.57 & 291.87 & Rozanski et al. (1993) \\
\hline Vernadsky & -65.08 & 296.02 & Rozanski et al. (1993) \\
\hline Vostok & -78.5 & 106.9 & Landais et al. (2012) \\
\hline$D D U$ & -66.7 & 140.00 & Jean Jouzel, personal communication, June 2017 \\
\hline Neumayer & -70.7 & 351.60 & Schlosser et al. (2008) \\
\hline Dome F & -77.3 & 39.7 & Fujita and Abe (2006) \\
\hline Dome C & -75.1 & 123.4 & Schlosser et al. (2017) \\
\hline \multicolumn{4}{|l|}{ (b) } \\
\hline EDC Dome C & -75.10 & 123.39 & Stenni et al. (2001) \\
\hline NUS 08-7 & -74.12 & 1.60 & Steig et al. (2013) \\
\hline NVFL-1 & -77.11 & 95.07 & Ekaykin et al. (2017) \\
\hline WDC06A & -79.46 & 247.91 & Steig et al. (2013) \\
\hline IND $25 B 5$ coastal DML & -71.34 & 11.59 & Rahaman et al. (2016) \\
\hline \multicolumn{4}{|l|}{ (c) } \\
\hline $\mathrm{OH}-4 *$ & -63.36 & 302.20 & Fernandoy et al. (2012) \\
\hline $\mathrm{OH}-5^{*}$ & -63.38 & 302.38 & Fernandoy et al. (2012) \\
\hline $\mathrm{OH}-6^{*}$ & -63.45 & 302.24 & Fernandoy et al. (2012) \\
\hline $\mathrm{OH}-9 *$ & -63.45 & 302.24 & Fernandoy et al. (2012) \\
\hline $\mathrm{OH}-10^{*}$ & -63.45 & 302.24 & Fernandoy et al. (2012) \\
\hline$K C$ & -70.52 & 2.95 & Vega et al. (2016) \\
\hline$K M$ & -70.13 & 1.12 & Vega et al. (2016) \\
\hline$B I$ & -70.40 & 3.03 & Vega et al. (2016) \\
\hline$G I P$ & -80.10 & 159.30 & Markle et al. (2012) \\
\hline DE08-2 & -66.72 & 112.81 & Delmotte et al. (2000) \\
\hline$D S S A$ & -66.77 & 112.81 & Delmotte et al. (2000) \\
\hline$D 15^{*}$ & -66.86 & 139.78 & Jean Jouzel, personal communication, June 2017 \\
\hline TA192A & -66.78 & 139.56 & This study \\
\hline
\end{tabular}

Finally, data associated with “*” were not provided with a dating while data in italics have a sub-annual resolution. Note that DE08-2 and D15 ice cores were not dated.

\subsubsection{Atmospheric reanalyses and back trajectories}

Unfortunately, because of the katabatic winds around DDU, no instrumental method allows reliable measurements of precipitation (Grazioli et al., 2017a). We use outputs from ERAInterim reanalyses (Dee et al., 2011b), which were shown to be relevant for Antarctic surface mass balance (Bromwich et al., 2011), to provide information on DDU intra-annual precipitation variability. We extracted these outputs from the grid point $\left(0.75^{\circ} \times 0.75^{\circ}, \sim 80 \mathrm{~km} \times 80 \mathrm{~km}\right.$, point centered at $66.75^{\circ} \mathrm{S}$ and $139.5^{\circ} \mathrm{E}$ ) closest to the TA drilling site over the period 1998-2014, at a $12 \mathrm{~h}$ resolution, and calculated daily, monthly, and annual average values. We also extracted $2 \mathrm{~m}$ temperature ( $2 \mathrm{mT}$ ), $10 \mathrm{~m} u$ and $v$ wind components (u10 and v10), and the geopotential height at $500 \mathrm{hPa}$ (z500) over the whole Southern Hemisphere $\left(50-90^{\circ} \mathrm{S}\right)$, in order to investigate potential linear relationships between our records and the large-scale climate variability.

In order to identify the origin of air masses, back trajectories were computed using the HYSPLIT (Hybrid SingleParticle Lagrangian Integrated Trajectory) model. It is an atmospheric transport and dispersion model developed by the National Oceanic and Atmospheric Administration (NOAA) Air Research Laboratory (Draxler and Hess, 1998), based on a mixing between Lagrangian and Eulerian approaches (Stein et al., 2015). We set the arrival point at the coordinates of the TA drilling site, at an initial height of $1500 \mathrm{~m}$ a.s.l., and used the NCEP/NCAR Global Reanalysis ARL archived 


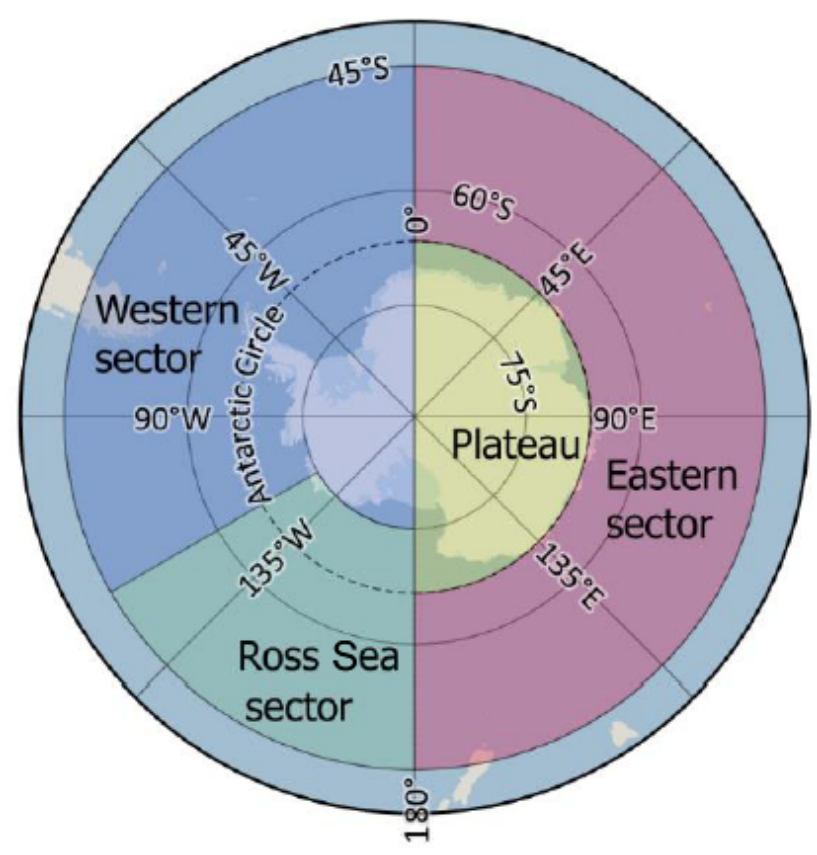

Figure 2. Representation of the sectors used to classify the last point of the simulated back trajectories by HYSPLIT over the period 1998-2014, defined as follows: (i) the eastern sector $\left(0-66^{\circ} \mathrm{S}\right.$, $\left.0-180^{\circ} \mathrm{E}\right)$, (ii) the plateau $\left(66-90^{\circ} \mathrm{S}, 0-180^{\circ} \mathrm{E}\right)$, (iii) the Ross Sea sector $\left(0-75^{\circ} \mathrm{S}, 180-240^{\circ} \mathrm{E}\right)$, and finally (iv) the western sector $(0$ $\left.75^{\circ} \mathrm{S}, 180-240^{\circ} \mathrm{E}\right)$ and $\left(50-90^{\circ} \mathrm{S}, 240-360^{\circ} \mathrm{E}\right)$.

data for forcing the meteorological conditions, as the ERAInterim reanalyses are not available in the required extension. Earlier studies (e.g. Markle et al., 2012; Sinclair et al., 2010) highlighted good performances of NCEP outputs when compared with Antarctic station data after 1979. For instance, previous studies showed that the mean sea level pressure simulated at DDU and averaged on a 5-year running window was well captured in NCEP reanalyses after 1986 (correlation coefficient $>0.8$, bias $<4 \mathrm{hPa}$, and RMSE $<5 \mathrm{hPa}$ ) (Bromwich and Fogt, 2004; Bromwich et al., 2007). Also, Simmons et al. (2004) showed quasi-equal 12-month running means of $2 \mathrm{~m}$ temperatures for the Southern Hemisphere between the European Re-Analyses ERA-40, the NCEP/NCAR, and the Climatic Research Unit CRUTEM2v products. We thus run daily 5-day back trajectories from January 1998 to December 2014. Each back trajectory was analysed for the geographical position of the last simulated point (the estimated start of the trajectory, 5 days prior to arrival at DDU) and classified into one of the following four regions, represented in Fig. 2 and defined by their longitude (long) and latitude (lat) as follows: (i) the eastern sector: $\left(0-66^{\circ} \mathrm{S}\right.$, $\left.0-180^{\circ} \mathrm{E}\right)$, (ii) the plateau: $\left(66-90^{\circ} \mathrm{S}, 0-180^{\circ} \mathrm{E}\right)$, (iii) the Ross Sea sector: $\left(0-75^{\circ} \mathrm{S}, 180-240^{\circ} \mathrm{E}\right)$, and finally (iv) the western sector: $\left(0-75^{\circ} \mathrm{S}, 180-240^{\circ} \mathrm{E}\right)$ and $\left(50-90^{\circ} \mathrm{S}, 240\right.$ $\left.360^{\circ} \mathrm{E}\right)$.

\subsubsection{Atmospheric general circulation and water stable isotope modelling: ECHAM5-wiso}

The potential relationships between large-scale climate variability and regional precipitation isotopic composition was also investigated through outputs of a nudged simulation performed with the atmospheric general circulation model ECHAM5-wiso (Roeckner et al., 2003), equipped with stable-water isotopes (Werner et al., 2011). We chose this model due to demonstrated skills to reproduce spatial and temporal patterns of water stable isotopes in Antarctica (Masson-Delmotte et al., 2008; Steen-Larsen et al., 2017; Werner et al., 2011; Goursaud et al., 2017) and in Greenland (Steen-Larsen et al., 2017).

In this study, we use the same simulation as Goursaud et al. (2017), in which the large-scale circulation (winds) and air temperature were nudged to outputs of the ERAInterim reanalyses (Dee et al., 2011a). The skills of the model were assessed over Antarctica for the period 1979-2014. The model was run in a T106 resolution (i.e. $\sim 110 \mathrm{~km} \times 110 \mathrm{~km}$ horizontal grid size). In the following, we used the subscripts $\mathrm{ECH}, \mathrm{TA}$, and S1C1 to differ ECHAM5-wiso outputs from the TA and S1C1 firn cores records respectively (e.g. $\delta^{18} \mathrm{O}_{\mathrm{TA}}$ and $\delta^{18} \mathrm{O}_{\mathrm{ECH}}$ ). Note also that linear relationships are considered significant when the $p$ value $<0.05$.

\subsubsection{Modes of variability}

We tested the main modes of variability were imprinted in our recorded, especially

- the Southern Annual Mode (SAM) using the index defined by Marshall (2003) and archived on the National Center for Atmospheric Research website (Marshall, Gareth \& National Center for Atmospheric Research Staff (Eds); last modified 19 March 2018; "The Climate Data Guide: Marshall Southern Annular Mode (SAM) Index (Station-based)"; retrieved from https://climatedataguide.ucar.edu/climatedata/marshall-southern-annular-mode-sam-index, last access: January 2018).

- the El Niño-Southern Oscillation (ENSO) using the El Niño 3.4 index defined by the Climate Prediction Center of NOAA's National Centers for Environmental Prediction and archived on their website (Trenberth, Kevin \& National Center for Atmospheric Research Staff Eds); last modified 06 September 2018; "The Climate Data Guide: Nino SST Indices (Nino 1+2, 3, 3.4, 4; ONI and TNI)"; retrieved from https://climatedataguide.ucar.edu/climate-data/ nino-sst-indices-nino-12-3-34-4-oni-and-tni, last access: January 2018).

- the Interdecadal Pacific Oscillation (IPO), using the IPO Tripole Index (TPI) defined by Henley et al. (2015) based on filtered HadISST and 
ERSSTv3b sea surface temperature data and archived on the internet (https://www.esrl.noaa.gov/psd/data/ timeseries/IPOTPI, last access: 20 September 2018).

- the Amundsen Sea Low pressure center (ASL) archived one the National Center for Atmospheric Research website (Hosking, Scott \& National Center for Atmospheric Research Staff Eds); last modified 19 March 2018; "The Climate Data Guide: Amundsen Sea Low indices"; retrieved from https://climatedataguide.ucar. edu/climate-data/amundsen-sea-low-indices, last access: January 2018).

\section{Results}

\subsection{Firn core chronology}

\subsubsection{Ice core dating}

The firn core was dated using an annual layer counting method (Fig. 3). As in Goursaud et al. (2017), we used concentrations in MSA and non-sea-salt (nss) $\mathrm{SO}_{4}^{2-}\left(\mathrm{nssSO}_{4}\right)$.

We have explored the validity of an approach using a definition of $\mathrm{nssSO}_{4}$ based on a sulfate-to-sodium mass ratio of 0.25 inferred from summer observations only. The multi-year study of size-segregated aerosol composition conducted at the coast of TA (the DDU station) has demonstrated that seasalt aerosol is depleted in sulfate with respect to sodium in winter, with a sulfate-to-sodium mass ratio of 0.13 from May to October instead of 0.25 (i.e. the seawater composition) in summer (Jourdain and Legrand, 2002). Even at the high plateau station of Concordia, Legrand et al. (2017a) showed that sea-salt aerosol is depleted in sulfate in winter (sulfateto-sodium ratio of 0.13 from May to October). We resampled the sulfate time series recorded in the TA with 12 points per year and inferred seasonal average values from averages over the corresponding subsets of points, as previously performed for isotopic records (Sect. 3.2). We then calculated $\mathrm{nssSO}_{4}$ (noted as $\mathrm{nssSO}_{4}^{*}$ ) using a sulfate-to-sodium ratio of 0.25 for points associated with months from November to February and 0.13 for points associated with months from March to September. Note that when ignoring the change in sulfateto-sodium ratio in winter (i.e. applying a sulfate-to-sodium ratio of 0.25 for all the points of the year), the mean $\mathrm{nssSO}_{4}$ value is lower by $18.2 \%$, decreasing from $36.5 \pm 12.3 \mathrm{ppb}$ to $43.1 \pm 11.8 \mathrm{ppb}$ for nssSO ${ }_{4}^{*}$ (Fig. S1 in the Supplement). We thus applied a calculation of $\mathrm{nssSO}_{4}$ for all points of our firn core, only using the sulfate-to-sodium ratio obtained from summer observations, as $\left[\mathrm{nssSO}_{4}^{2-}\right]=\left[\mathrm{SO}_{4}^{2-}\right]-0.25\left[\mathrm{Na}^{+}\right]$.

For depths lower than $10 \mathrm{~m}$ w.e., summer (DecemberJanuary) peaks were identified (i) from nss $\mathrm{SO}_{4}$ values higher than $100 \mathrm{ppb}$, synchronous with MSA peaks (with no threshold), and (ii) for nssSO 4 values higher than $200 \mathrm{ppb}$ (with or without a simultaneous MSA peak). Double $\mathrm{nssSO}_{4}$ peaks were counted as one summer (e.g. 2012, 2003, and 2001).
For depths higher than $10 \mathrm{~m}$ w.e., summer peaks were identified for $\mathrm{nssSO}_{4}$ values higher than $27 \mathrm{ppb}$. The outcome of layer counting allowed us to estimate annual layer thickness, which, combined with the density profile, allowed us to estimate annual SMB in the firn core. This estimated SMB was then compared with stake area data. The three stake data closest to the TA firn core $(18.3,19.2$, and 20.3, not shown) depict the same inter-annual variability (pairwise coefficient correlations, $r>0.93$ and $p$ values, $p<0.05$ ), giving confidence in the use of these measurements to characterize the inter-annual variability of local SMB. The comparison with the stake data shows that our initial layer-counted chronology results in a mismatch in the measured versus estimated SMB for the year 2008 (Fig. 4a). This mismatch can be resolved by identifying one more summer peak in the chemical records (thin green line, Fig. 3). The revised firn core SMB record from this revised chronology shows correlation coefficients between the stake data and the TA firn core varying from 0.64 for 20.3 to 0.83 for 19.2 ( $p<0.05$ ), with coherent inter-annual variability (Fig. 4b)

Peaks in $\delta^{18} \mathrm{O}_{\mathrm{TA}}$ or $d$-excess $\mathrm{TA}$ were not used in our layer counting, so that our age scale is independent of a climatic interpretation of water stable isotopes (e.g. assumption of synchronicity between temperature seasonal cycles and water stable isotope records). We note an uncertainty in layer counting of 3 years when comparing the outcome of layer counting using chemical records with $\delta^{18} \mathrm{O}_{\mathrm{TA}}$ peaks, which have nonetheless been excluded from our dating, as they do not improve the correlations, either between the reconstructed SMB and the stake data or between our records and the ECHAM5-wiso simulations (Tables S1 to S3).

As a result, we consider the "best guess" chronology results from the annual layer counting based on $\mathrm{nssSO}_{4}$ and MSA refined with the comparison with stake data, giving a total of 18 summer peaks (green vertical lines, Fig. 3). In the following, we thus use the dated firn core records covering the complete period 1998-2014. We note that our chronology is more robust for the period 2004-2014, for which stake area SMB data are available.

\subsubsection{Potential post-deposition effects}

In order to test whether the available $d$-excessTA records are not affected by post-deposition effects, one may apply calculations of diffusion (e.g. Jones et al., 2017; Johnsen et al., 2000; van der Wel et al., 2015). However, many records are not available as depth profiles, and annual accumulation rate data are missing, precluding a systematic approach. We thus applied a simple approach to quantify how the seasonal $\delta^{18} \mathrm{O}_{\mathrm{TA}}$ and $d$-excess $\mathrm{TA}$ amplitudes vary through time in firn records, as an indicator of potential post-diffusion effects. For this purpose, we calculate the ratio between the mean amplitude of the most recent three complete seasonal cycles (2011-2014 for TA) and the average seasonal amplitude for the whole record (1998-2014 for TA). If seasonal cycles are 

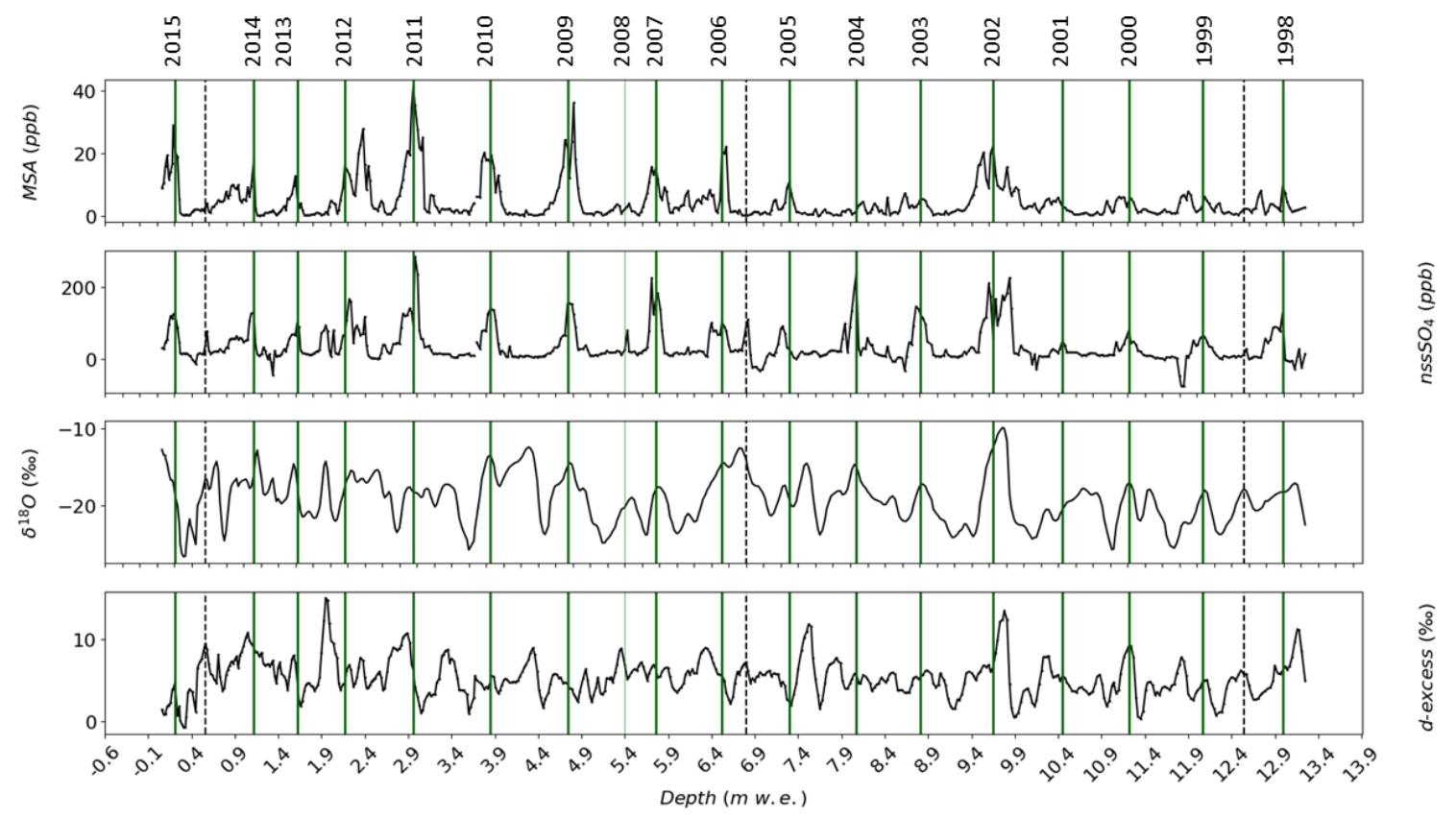

Figure 3. Identification of annual layers in the TA192A ice core based on the dual identification of nssSO ${ }_{4}^{2-}$ and $\mathrm{MSA}^{2}$ summer peaks and comparison of estimated accumulation with annual accumulation measured at the closest stakes (not shown). The thick vertical green lines correspond to summer peaks identified from chemical signals, while the thin vertical green line shows the additional identification of summer 2008 added to the counted summers from the comparison between the estimated accumulation and the accumulation record from the closest stake data (see Fig. 3). Vertical dashed lines highlight equivocal summer peaks with a sometimes small signal in only one of the chemical records. Water stable isotope records were not used to build the timescale. Note that double peaks in both $\delta^{18} \mathrm{O}$ and $d$-excess occur repeatedly within one counted year.

stable through time, and if there is no significant smoothing due to post-deposition effects, we should obtain a ratio of 1 . However, it is expected to be above 1 in the case of large post-deposition smoothing. We obtain a ratio of 0.5 for $\delta^{18} \mathrm{O}_{\mathrm{TA}}$ data, possibly reflecting the inter-annual variability of the $\delta^{18} \mathrm{O}$ seasonal amplitude. We repeated the same exercise with all eight other sub-annual $\delta^{18} \mathrm{O}$ records from our database (Table S4). Discarding an outlier (NUS 08-7), all ratios are between 1.0 and 2.9. Ratios based on $d$-excess amplitudes are similar to those found for $\delta^{18} \mathrm{O}$ (Table S5). For the TA firn core, we again obtain a ratio of 1.1 for $d$-excess TA $_{\text {TA }}$. We also note high ratios for $d$-excess data in the NUS 08-7. Except for the ratios calculated in the WDC06A, which notably differs for $d$-excess (1.1) compared to $\delta^{18} \mathrm{O}(2.9)$, other ratios for $d$-excess data vary between 1.0 and 1.4 , with $20 \%$ maximum difference compared to the corresponding ratio for $\delta^{18} \mathrm{O}$ data.

For the TA, we also estimated the diffusion length (Küttel et al., 2012) and found mean diffusion lengths of $1.4 \pm$ 0.3 months for $\delta^{18} \mathrm{O}_{\mathrm{TA}}$ (with a maximum of 1.9 months in 2007 ) and $1.6 \pm 0.5$ months for $d$-excess TA $_{\mathrm{TA}}$ (with a maximum of 2.4 months in 2007).

These results suggest that potential post-deposition effects in the TA can be neglected. Notwithstanding, a potential loss of seasonal amplitude in the other average time series com- pared to the most recent seasonal cycles cannot be discarded and has to be considered in the comparison of seasonal amplitudes, from one core to the other, in the comparison with the seasonal amplitude of precipitation $\delta^{18} \mathrm{O}$ time series, and with ECHAM5-wiso outputs.

\subsection{Mean values}

\subsubsection{Mean climate from instrumental data}

Before reporting the mean values from TA records, we describe the available meteorological data. A time-averaged statistical description of the available meteorological data measured at DDU, the station closest to the drilling site, is given in Table 2 for the whole available measurement period prior to 2015 (1957-2014) and over the period covered by our TA records, 1998-2014. For all the considered parameters (near-surface temperature, wind direction, wind speed, humidity, and surface pressure), the time-averaged values differ by less than $8 \%$ (the maximum deviation being for the wind direction) over the period 1998-2014 compared to the whole available period. Standard deviations calculated over these two time periods also differ by less than one respective standard deviation unit, except for wind direction, which shows much less variability over the recent period. We conclude that the local climate of the period 

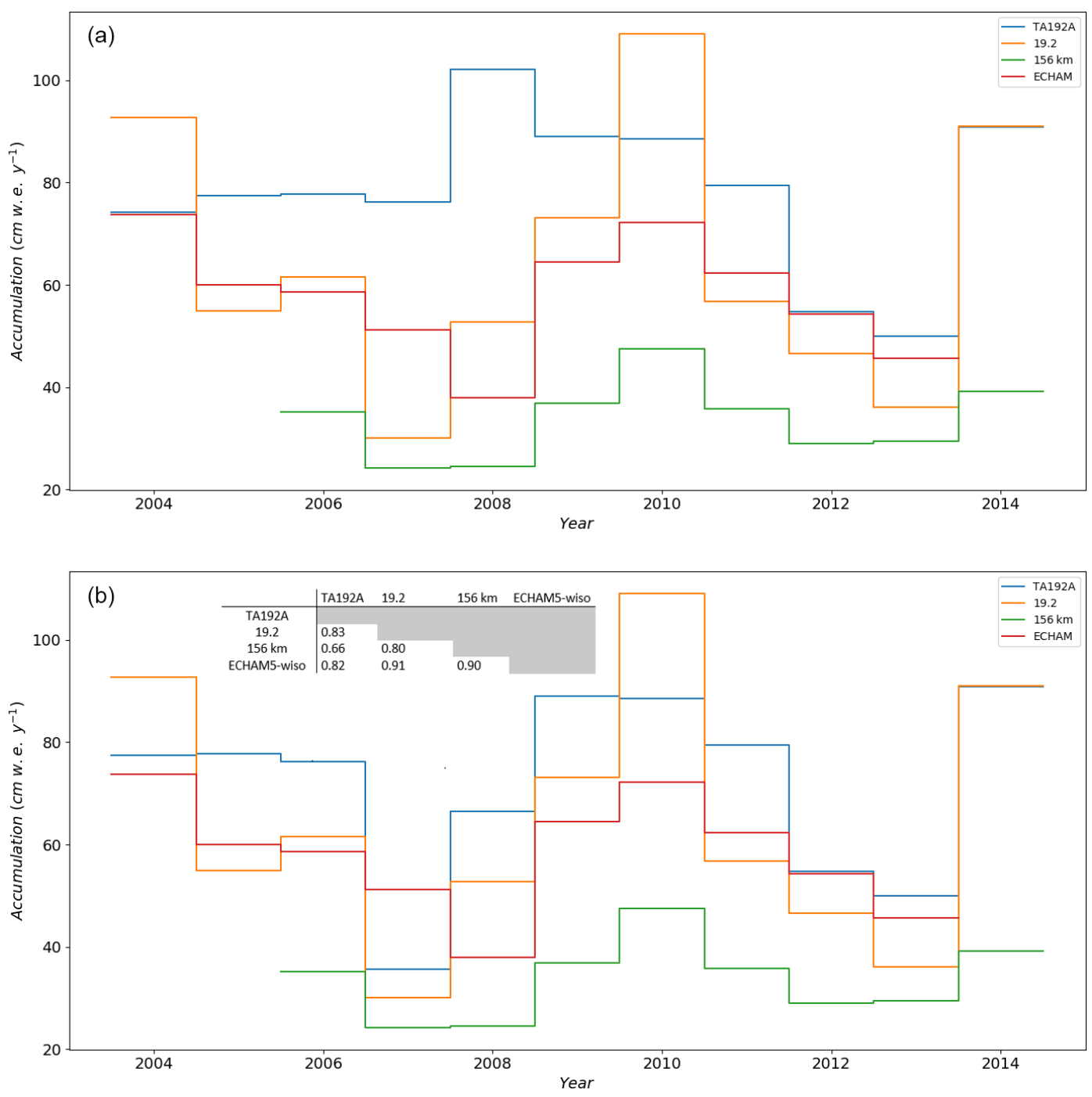

Figure 4. Annual accumulation ( $\mathrm{cm}$ w.e. $\mathrm{yr}^{-1}$ ) estimated from the layer counting in the TA192A firn core (blue line), measured at the closest stake point 19.2 (orange line), from the $156 \mathrm{~km}$ network stake data (green line) and extracted from the ECHAM5-wiso model (red line), before (a) and after (b) adding the identification of summer 2008 in a time interval of low accumulation rates and skipped in the initial layer-counting approach due to the lack of a signal in the MSA record (thin green line in Fig. 2). Correlations between time series (TA192A series inferred from the second dating) are inserted in the lower plot, with all linear relationships being significant $(p<0.05)$.

1998-2014 is representative of the multi-decadal climate state since 1957. In ERA-Interim, the average precipitation is $46.0 \pm 26.9 \mathrm{~cm}$ w.e. $\mathrm{yr}^{-1}$ over the period $1998-2014$.

Finally, we compare the statistical description of the sea ice concentration for the four aforementioned regions (Sect. 2.2) over the available period 1979-2014, with the period covered by the TA firn core 1998-2014 (Table 3). We note that the mean difference between the two periods is maximum for the local sea ice concentration $\left(135-145^{\circ} \mathrm{E}\right)$, with $8.9 \%$ difference, whereas it remains below $1.5 \%$ for the other sectors. The extrema (minimum and maximum values) vary by $0.5 \%$ on average (all regions included) from one sector to another, with a maximum difference of $2.9 \%$. As a result, the mean sea ice concentrations of the period 1998
2014 are also representative for the last decades over large sectors from the Amundsen Sea to Indian Ocean.

\subsubsection{Mean values recorded in the TA firn core}

Time-averaged values calculated from $\mathrm{TA}$ records are reported in Table 4. The average $\mathrm{SMB}_{\mathrm{TA}}$ is $75.2 \pm$ $15.0 \mathrm{~cm}$ w.e. $\mathrm{yr}^{-1}$. Stake data points from GLACIOCLIM show that this site of high accumulation is located in an area of large spatial variability. This feature is confirmed by the values given by (i) the stake data closest to the TA site $(19.2,100 \mathrm{~m}$ for the TA site and associated with a $76.6 \pm$ $25.8 \mathrm{~cm}$ w.e. $\mathrm{yr}^{-1}$ mean accumulation rate) compared to further stake data $(18.2,1.04 \mathrm{~km}$ from the TA site and associ- 
Table 2. Number of points $(n)$, time averages $(\mu)$, standard deviation $(\sigma)$, minimum (min), and maximum (max) values of all the monthly meteorological observations at Dumont d'Urville from Météo France over the period 1957-2014 (with a gap between March 1959 and January 1960, inclusive) and over the period 1998-2014 for near-surface temperature $\left(T_{\mathrm{s}}\right.$, ${ }^{\circ} \mathrm{C}$ ), wind speed (ws, $\left.\mathrm{ms}^{-1}\right)$, wind direction (wd, ${ }^{\circ} \mathrm{E}$ ), relative humidity (RH, \%), and annual precipitation and accumulation (precipitation minus evaporation and sublimation) from ERA-Interim reanalyses (Prec. ERA, $\mathrm{mm}_{\mathrm{w}}$.e. $\mathrm{yr}^{-1}$ ).

\begin{tabular}{lrrrrrrrrr}
\hline & & \multicolumn{2}{c}{$1957-2014$} & & & & & & \\
\cline { 3 - 7 } & $T_{\mathrm{S}}$ & $\begin{array}{r}\text { ws } \\
\left({ }^{\circ} \mathrm{C}\right)\end{array}$ & $\begin{array}{r}\text { wd } \\
\left(\mathrm{m} \mathrm{s}^{-1}\right)\end{array}$ & $\begin{array}{r}\text { RH } \\
\left({ }^{\circ} \mathrm{E}\right)\end{array}$ & $\begin{array}{r}T_{\mathrm{S}} \\
(\%)\end{array}$ & $\begin{array}{r}\text { ws } \\
\left({ }^{\circ} \mathrm{C}\right)\end{array}$ & $\begin{array}{r}\text { wd } \\
\left(\mathrm{m} \mathrm{s}^{-1}\right)\end{array}$ & $\begin{array}{r}\text { RH } \\
\left({ }^{\circ} \mathrm{E}\right)\end{array}$ & $\begin{array}{r}\text { Prec. ERA } \\
(\%)\end{array}$ \\
\hline$n$ & 730 & 719 & 383 & 717 & 202 & 201 & 201 & 199 & \\
& -10.9 & 9.6 & 145.3 & 61.4 & -11.1 & 9.1 & 133.8 & 60 & 46.0 \\
$\mu$ & 6 & 2.1 & 22.4 & 7.6 & 6.0 & 1.8 & 15.8 & 8.3 & 26.9 \\
$\sigma$ & 23.5 & 4.9 & 90 & 34 & -22.1 & 4.8 & 1.5 & 34.0 & 1.5 \\
Min & 1 & 19.5 & 220 & 86 & 0.9 & 14.1 & 172.4 & 85.5 & 147.8 \\
Max & 1 & & & & & & & & \\
\hline
\end{tabular}

Table 3. Number of points $(n)$, time averages $(\mu)$, standard deviation $(\sigma)$, minimum (min), and maximum (max) values of monthly meteorological sea ice concentration over the periods 1979-2014 and 1998-2014 extracted from the Nimbus-7 Scanning Multichannel Microwave Radiometer (SMMR) and Defense Meteorological Satellite Program Special Sensor Microwave/Imagers - Special Sensor Microwave Image/Sounder (DMSP SSM/I-SSMIS) passive microwave data (http://nsidc.org/data/nsidc-0051, last access: January 2018) (Cavalieri et al.,

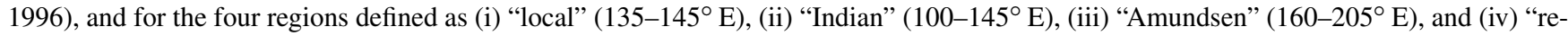
gional" (100-205 E).

\begin{tabular}{lrrrr|rrrr}
\hline & \multicolumn{4}{c|}{$1979-2014$} & \multicolumn{4}{c}{$1998-2014$} \\
\cline { 2 - 8 } & Indian & Local & Amundsen & Regional & Indian & Local & Amundsen & Regional \\
\hline$n$ & 432 & 432 & 432 & 432 & 204 & 204 & 204 & 204 \\
$\mu$ & 41.1 & 47.0 & 56.6 & 42.9 & 41.6 & 51.2 & 57.4 & 43.4 \\
$\sigma$ & 6.8 & 7.7 & 11.5 & 8.7 & 6.6 & 8.0 & 11.6 & 8.8 \\
Min & 31.0 & 38.2 & 36.3 & 28.7 & 31.1 & 38.4 & 36.6 & 28.9 \\
Max & 55.4 & 66.0 & 74.2 & 58.8 & 53.8 & 65.2 & 73.9 & 57.7 \\
\hline
\end{tabular}

ated with a $47.7 \pm 15.7 \mathrm{~cm}$ w.e. $\mathrm{yr}^{-1}$ mean accumulation rate), (ii) our mean $\mathrm{SMB}$ reconstruction from the $\mathrm{S} 1 \mathrm{C} 1$ ice core al-

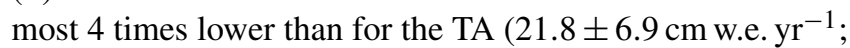
Goursaud et al., 2017), and (iii) mesoscale fingerprints such as the SMB estimated for coastal Adélie Land by Pettré et al. (1986), based on measurements at stakes located from $500 \mathrm{~m}$ to $5 \mathrm{~km}$ from the coast (Table 2).

The average $\delta^{18} \mathrm{O}_{\mathrm{TA}}$ value is $-19.3 \% \circ \pm 3.1 \%$, close to the average $\delta^{18} \mathrm{O}_{\mathrm{S} 1 \mathrm{C} 1}$ of $-18.9 \% \circ \pm 1.7 \%$, and the average $d$-excess $\mathrm{TA}$ is $5.4 \% \circ \pm 2.2 \%$. Compared to the 64 points located at an elevation lower than $1000 \mathrm{~m}$ a.s.l. from our database, the $\delta^{18} \mathrm{O}_{\mathrm{TA}}$ and $d$-excess are slightly higher than the average low-elevation records $\left(-22.7 \% \circ \pm 8.8 \%\right.$ and $4.8 \% \circ \pm 2.3 \%$ for $\delta^{18} \mathrm{O}$ and $d$-excess respectively, Fig. 5). Finally, the average TA concentrations in $\mathrm{Na}^{+}, \mathrm{MSA}$, and $\mathrm{nssSO}_{4}$ are $126.0 \pm 276.5,4.5 \pm 5.6$, and $36.5 \pm 44.2 \mathrm{ppb}$ respectively. Note that the $\mathrm{Na}^{+}$average concentration value is affected by strong peaks in 2003 and 2004 with annual values of 369.4 and 388.5 ppb. Excluding these two peaks, the average $\mathrm{Na}^{+}$concentration is reduced to $93.2 \mathrm{ppb}$ (with a standard deviation of $38.6 \mathrm{ppb}$ ). These concentrations will be discussed later in Sect. 4.4.
To summarize our findings, the TA records encompass a period (1998-2014) representative of multi-decadal mean climatic conditions. The isotopic mean values appear lower than the average of other Antarctic low-elevation records (as shown in Fig. 4). The local SMB is remarkably high for East Antarctica, consistent with stake measurements performed close to the TA site.

\subsection{Inter-annual variations}

In the following, we refer to seasons as follows: summer (December to February), autumn (March to May), winter (June to September), and spring (October and November). This cutting was defined based on the mean seasonal cycle of temperature, showing the highest values from December to February, and a plateau of low values from May to September (Fig. 8a). In the TA records, resampled with 12 points per year, we identified seasonal average values by calculating averages over the corresponding subsets of points (e.g. for autumn, we select from the third to the fifth points out of the 12 resampled points within the year). We are fully aware that this is a simplistic approach, assuming a regular distribution of precipitation year round, and that our chronology is 
Table 4. Time averages $(\mu)$ and standard deviation $(\sigma)$ of the reconstructed accumulation (cm w.e.) and of the signals recorded in the TA192A ice core obtained from the resampling of the isotopic and chemical variables for $\delta^{18} \mathrm{O}(\%), d$-excess $(\%$ o), $\mathrm{Na}, \mathrm{MSA}$, and nssSO 4 (ppb), over the 17 annual values.

\begin{tabular}{rrrrrrr}
\hline & $\begin{array}{r}\text { Accumulation } \\
(\mathrm{cm} \text { w.e. })\end{array}$ & $\begin{array}{r}\delta^{18} \mathrm{O} \\
(\% \circ)\end{array}$ & $\begin{array}{r}d \text {-excess } \\
(\% o)\end{array}$ & $\begin{array}{r}\mathrm{Na}^{+} \\
(\mathrm{ppb})\end{array}$ & $\begin{array}{r}\mathrm{MSA} \\
(\mathrm{ppb})\end{array}$ & $\begin{array}{r}\mathrm{nssSO}_{4} \\
(\mathrm{ppb})\end{array}$ \\
\hline$\mu$ & 75.2 & -19.3 & 5.4 & 126.0 & 4.5 & 36.5 \\
$\sigma$ & 15.0 & 3.1 & 2.2 & 276.5 & 5.6 & 44.2 \\
\hline
\end{tabular}
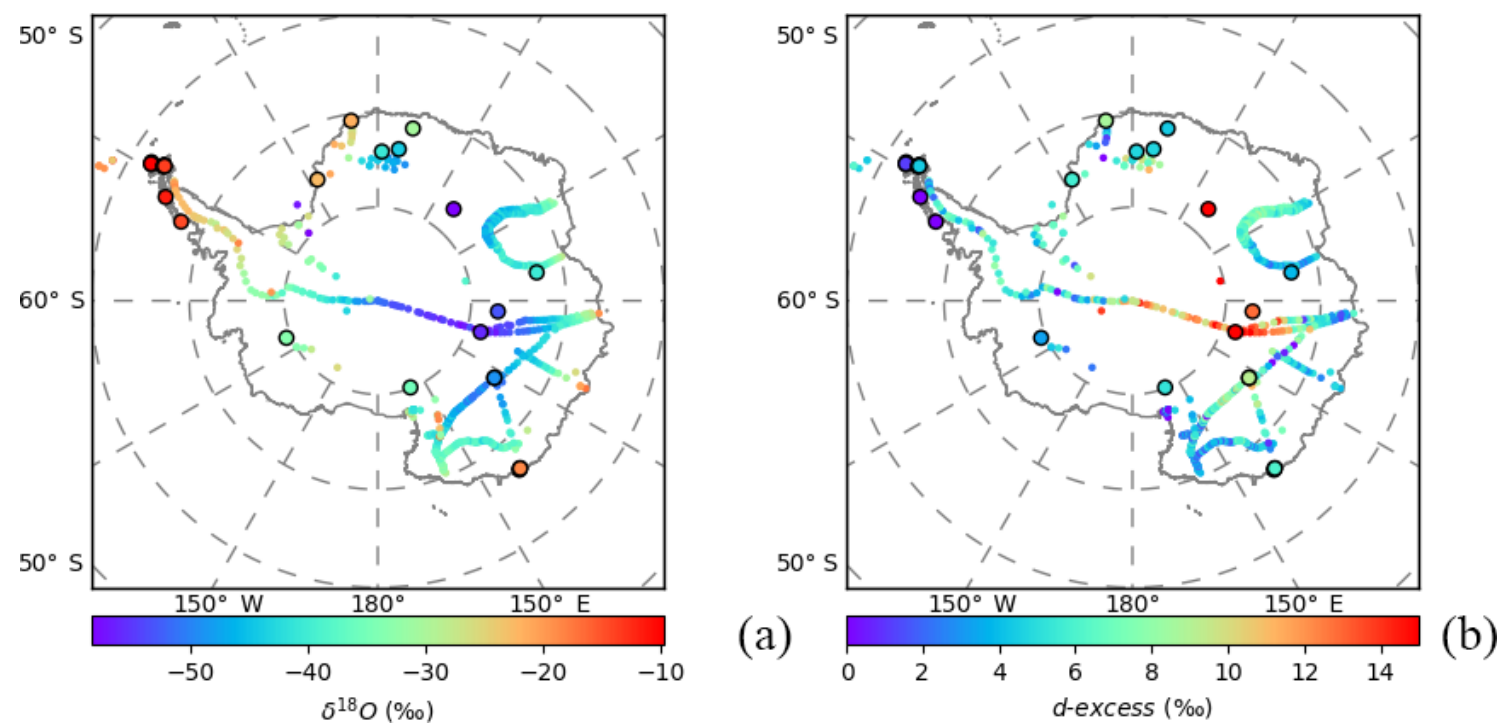

Figure 5. Spatial distribution of $\delta^{18} \mathrm{O}(\mathbf{a}, \%)$ and $d$-excess $(\mathbf{b}, \%)$ in surface Antarctic snow based on our updated database combining data from precipitation, surface snow, pits, and shallow ice cores. Bigger points with a black edge correspond to new data compared to Masson-Delmotte et al. (2008).

more accurate for summer than for other seasons, due to the layer-counting method. We nevertheless checked that the distribution of precipitation simulated by ERA-Interim within each year is rather homogeneous (Table S6).

\subsubsection{Trends in time series}

Here we report the analysis of potential trends from 1998 to 2014 and the identification of remarkable years. Figures 6 and 7 display the time series of meteorological variables, Dumont d'Urville summer sea ice extent and TA records over 1998-2014. In Figs. 6 and 7, we chose not to display standard deviations for readability, but they are reported in the Supplement (Figs. S2 and S3).

Significant increasing trends are detected in the annual values of $d$-excess $\mathrm{TA}\left(0.11 \% \circ \mathrm{yr}^{-1}, r=0.61\right.$ and $\left.p<0.05\right)$ as well as of Dumont d'Urville summer sea ice extent $(r=$ $0.77, p<0.05)$.

\subsubsection{Pairwise linear regressions between variables}

We performed pairwise linear regressions for all records (meteorological and firn core records), using, on the one side, annual averages and, on the other side, monthly or seasonal values. As previously observed by Comiso et al. (2017), we report a significant anti-correlation between annual regional sea ice concentration (i.e. $100-205^{\circ} \mathrm{E}$, but not with other sectors) and DDU near-surface air temperature $(r=-0.56$ and $p<0.05)$. This relationship is strongest in autumn ( $r=$ -0.75 and $p<0.05$ ), where it holds for sea ice in all sectors, and disappears in spring or summer. Confirming earlier studies (Minikin et al., 1998), we observe a close correlation between annual concentrations of MSA and $\mathrm{nsSSO}_{4}(r=0.76$, $p<0.05)$. Statistically significant linear relationships appear between the isotopic signals $\left(\delta^{18} \mathrm{O}_{\mathrm{TA}}\right.$ and $d$-excess $\left.\mathrm{TA}\right)$ and $\mathrm{nsSSO}_{4}$ in spring $\left(r=0.65\right.$ and $r=0.55$ for $\delta^{18} \mathrm{O}_{\mathrm{TA}}$ and $d$-excess $\mathrm{TA}$ respectively, $p<0.05$ ) and only between $d$ excess $_{\mathrm{TA}}$ and $\mathrm{nssSO}_{4}$ in autumn $(r=0.65$ and $p<0.05)$. We find no relationship between $\delta^{18} \mathrm{O}_{\mathrm{TA}}$ and the DDU nearsurface temperature. Our record depicts a significant anticorrelation between annual values of $\mathrm{SMB}_{\mathrm{TA}}$ and $d$-excess $\mathrm{TA}_{\mathrm{TA}}$ $(r=-0.59$ and $p<0.05)$, as well as a significant correlation between $d$-excessTA and Dumont d'Urville summer sea ice extent $(r=0.65$ and $p<0.05)$. Finally, a systematic positive significant correlation is identified between $d$-excess $\mathrm{TA}$ 


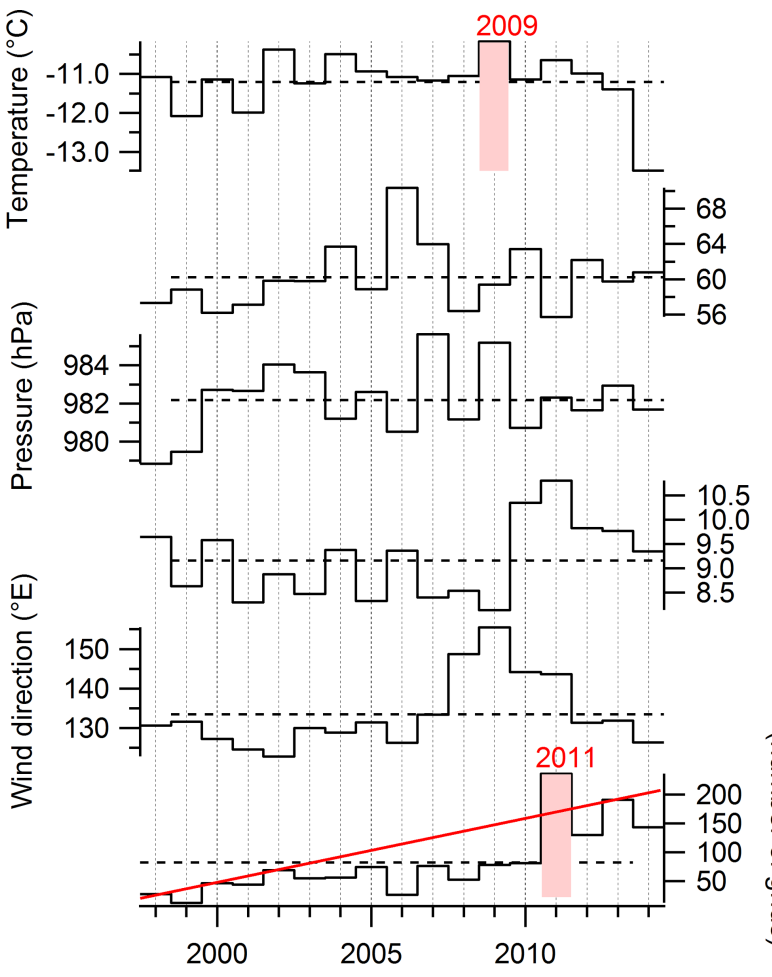

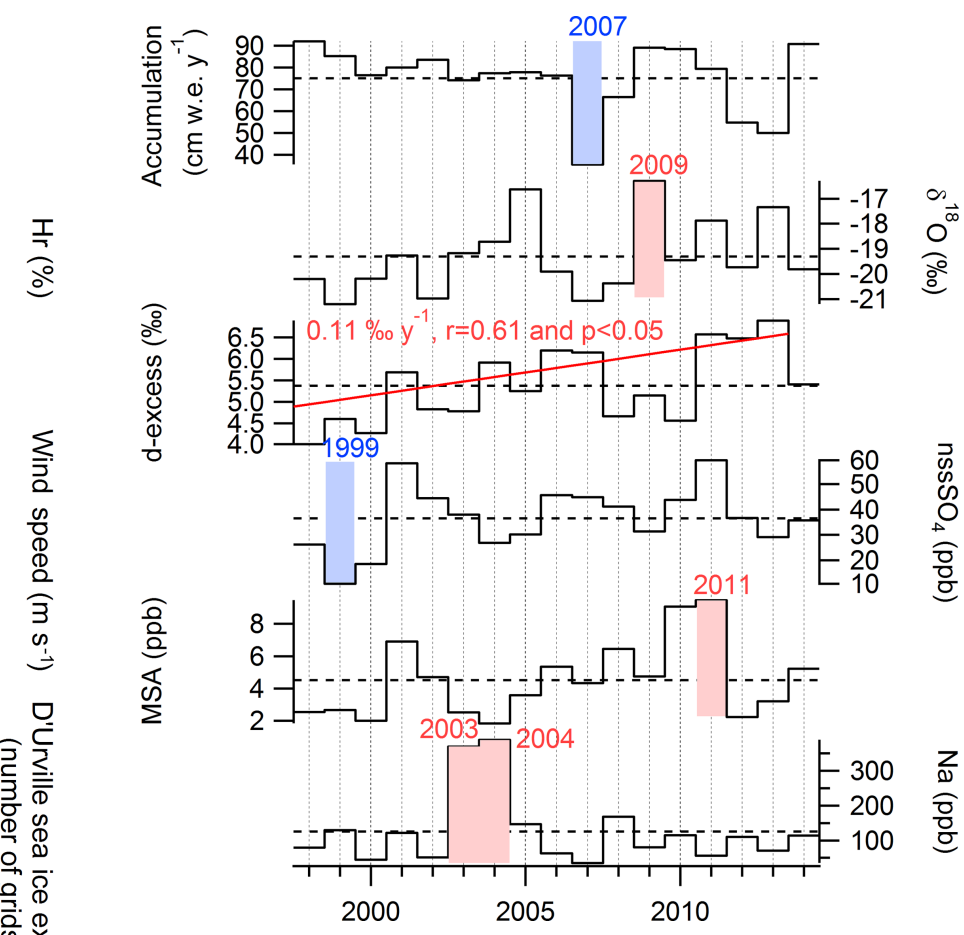

Figure 7. Dated TA192A ice core annually averaged records over the period 1998-2014: accumulation, $\mathrm{cm}$ w.e. $\mathrm{yr}^{-1}$; concentrations of $\mathrm{Na}+(\mathrm{ppb}), \mathrm{nssSO}_{4}(\mathrm{ppb}), \mathrm{MSA}(\mathrm{ppb}), \delta^{18} \mathrm{O}(\%)$, and $d$-excess (\%o). Horizontal dashed lines correspond to 1998-2014 average values. Remarkable years (i.e. associated with values deviating by at least 2 standard deviations from the climatological mean value) are highlighted with red shading (positive anomalies) or blue shading (negative anomalies). The same figure with standard deviations is available in the Supplement (Fig. S3).

shows a positive relationship, similar to the one identified in the TA record. We conclude that the positive correlation observed in the TA records is specific to the coastal Adélie Land region, which is unusual in an Antarctic context.

\subsubsection{Remarkable years}

Using only annual SMB, water stable isotope, and chemistry TA records, we finally searched for remarkable years, defined here as deviating from the 1998-2014 mean value by at least 2 standard deviations. We highlight three remarkable years (red-shaded for high values and blue-shaded for low values, Figs. 6 and 7):

- 2007, with very low $\mathrm{SMB}_{\mathrm{TA}}$;

- 2009, with remarkably high $\delta^{18} \mathrm{O}_{\mathrm{TA}}$;

- 2011, with high MSA, Dumont d'Urville summer sea ice extent, and wind speed values.

We had previously noted that the years 2003 and 2004 are associated with very high $\mathrm{Na}^{+}$values and add that the year 1999 experienced low $\mathrm{nssSO}_{4}$ values. 
Table 5. The $d$-excess versus $\delta^{18} \mathrm{O}$ linear relationship of data from our database provided with $d$-excess over the whole time series (left side of the table) and over annual averages (inter-annual scale, right side of the table): slope $\left(\% \%_{0}{ }^{-1}\right)$, correlation coefficient $(r), p$ value $(p$ val), and standard error of the slope (SE, $\left.\% \%_{0}^{-1}\right)$. Cells in bold show a significant relationship $(p<0.05)$ and the cell in italic is to be taken with caution (see DDU line, $p<0.10$ ). Inter-annual relationships could not be computed for undated data (D15 and OH ice cores) or for precipitation data monitored for too short of a time and thus appear as empty cells.

\begin{tabular}{|c|c|c|c|c|c|c|c|c|c|c|}
\hline & \multicolumn{5}{|c|}{ Whole time series } & \multicolumn{5}{|c|}{ Inter-annual scale } \\
\hline & $\begin{array}{l}\text { Number } \\
\text { of points }\end{array}$ & $\begin{array}{r}\text { Slope } \\
\left(\% \circ \% o^{-1}\right)\end{array}$ & $R$ & $p$ val & $\mathrm{SE}$ & $\begin{array}{l}\text { Number } \\
\text { of points }\end{array}$ & $\begin{array}{r}\text { Slope } \\
\left(\% \circ \% o^{-1}\right)\end{array}$ & $r$ & $p$ val & SE \\
\hline EDC Dome C & 140 & -0.41 & -0.31 & 0.00 & 0.11 & 623 & -0.41 & $-\mathbf{0 . 3 1}$ & 0.00 & 0.11 \\
\hline NUS 08-7 & 2413 & -0.36 & -0.28 & 0.00 & 0.08 & 626 & -0.36 & -0.28 & 0.00 & 0.08 \\
\hline NUS 07-1 & 299 & 0.17 & 0.25 & 0.15 & 0.12 & 299 & 0.17 & 0.25 & 0.15 & 0.12 \\
\hline NVFL-1 & 233 & 0.47 & 0.40 & 0.00 & 0.02 & 233 & 0.47 & 0.40 & 0.00 & 0.02 \\
\hline WDC06A & 41120 & 0.25 & 0.25 & 0.00 & 0.00 & 2056 & 0.05 & 0.06 & 0.01 & 0.02 \\
\hline IND 25B5 & 1297 & 0.17 & 0.08 & 0.45 & 0.22 & 140 & 0.17 & 0.08 & 0.45 & 0.22 \\
\hline BI & 404 & 0.01 & 0.02 & 0.70 & 0.03 & 17 & -0.57 & -0.57 & 0.01 & 0.20 \\
\hline KC & 343 & 0.22 & 0.23 & 0.00 & 0.05 & 48 & 0.05 & 0.06 & 0.70 & 0.12 \\
\hline KM & 425 & 0.04 & 0.06 & 0.24 & 0.04 & 18 & -0.86 & -0.57 & 0.01 & 0.29 \\
\hline DSSA & 161 & -0.03 & -0.04 & 0.58 & 0.05 & 6 & -0.41 & -0.74 & 0.04 & 0.15 \\
\hline DE08-2 & 58 & -0.11 & -0.08 & 0.57 & 0.19 & 58 & -0.11 & -0.08 & 0.57 & 0.19 \\
\hline D15-1 & 126 & -0.03 & -0.03 & 0.72 & 0.07 & & & & & \\
\hline D15-2 & 191 & -0.06 & -0.10 & 0.19 & 0.04 & & & & & \\
\hline $\mathrm{OH} 4$ & 318 & -0.11 & -0.11 & 0.13 & 0.07 & & & & & \\
\hline OH5 & 213 & -0.05 & -0.04 & 0.45 & 0.07 & & & & & \\
\hline OH6 & 124 & 0.01 & 0.01 & 0.86 & 0.08 & & & & & \\
\hline OH9 & 232 & -0.05 & -0.04 & 0.57 & 0.08 & & & & & \\
\hline $\mathrm{OH} 10$ & 190 & -0.10 & -0.04 & 0.58 & 0.17 & & & & & \\
\hline$D D U$ & 19 & 0.48 & 0.41 & 0.08 & 0.26 & & & & & \\
\hline Dome C & 501 & -1.48 & -0.84 & 0.00 & 0.04 & 4 & -2.75 & -0.98 & 0.02 & 0.42 \\
\hline Dome $\mathbf{F}$ & 351 & -1.60 & -0.89 & 0.00 & 0.05 & & & & & \\
\hline Halley & 532 & -0.20 & -0.18 & 0.00 & 0.05 & 49 & -0.23 & -0.12 & 0.41 & 0.28 \\
\hline Marsh & 19 & -0.86 & -0.51 & 0.03 & 0.35 & & & & & \\
\hline Neumayer & 336 & -0.06 & -0.07 & 0.21 & 0.05 & 19 & 0.28 & 0.31 & 0.20 & 0.21 \\
\hline Rothera & 194 & -1.00 & -0.58 & 0.00 & 0.10 & 18 & -1.21 & -0.86 & 0.00 & 0.18 \\
\hline Vernadsky & 372 & -1.33 & -0.57 & 0.00 & 0.08 & 35 & -1.89 & -0.69 & 0.00 & 0.29 \\
\hline Vostok & 27 & -0.73 & -0.63 & 0.00 & 0.18 & & & & & \\
\hline
\end{tabular}

In summary, we identify increasing trends in $d$-excess TA and sea ice concentration, no significant correlation between $\delta^{18} \mathrm{O}_{\mathrm{TA}}$ and DDU near-surface temperature, and an anticorrelation between $d$-excess TA $_{\text {end }}$ anB $\mathrm{SMA}_{\mathrm{TA}}$. We also note two remarkable years in $\mathrm{SMB}_{\mathrm{TA}}$ (dry 2007) and $\delta^{18} \mathrm{O}_{\mathrm{TA}}$ (high 2009). Finally, no systematic relationships are identified between chemistry and water stable isotope signals (e.g. parallel trends, inter-annual correlation, and remarkable years).

\subsection{Intra-annual scale}

\subsubsection{Mean cycles}

The high resolution of the TA record allows us to describe the mean seasonal cycles (Fig. 8), as well as to explore the inter-annual variability of the seasonal cycle.
Among the meteorological variables, only near-surface temperature, relative humidity, and sea level pressure show a clear seasonal cycle. Temperature (Fig. 8a) is minimum in July and maximum in January, while relative humidity and pressure (Fig. $8 \mathrm{~b}$ and c respectively) are minimum in spring (in November and October respectively) and maximum in winter (in August and June respectively), as reported in earlier studies (Pettré and Périard, 1996). The average seasonal cycles of wind speed and wind direction are flat but marked by large inter-annual variations (Fig. 8d and e). Finally, the local sea ice concentration shows a rapid advance from March to June, a plateauing from June to October, and a rapid retreat from October to November, with a minimum in February (Fig. 8c), as previously reported by Massom et al. (2013).

In the TA firn core, $\mathrm{Na}, \mathrm{nssSO}_{4}$, and MSA show symmetric cycles with minima in winter and maxima in summer (by construction of our timescale) (Fig. 8g-i), consistent 

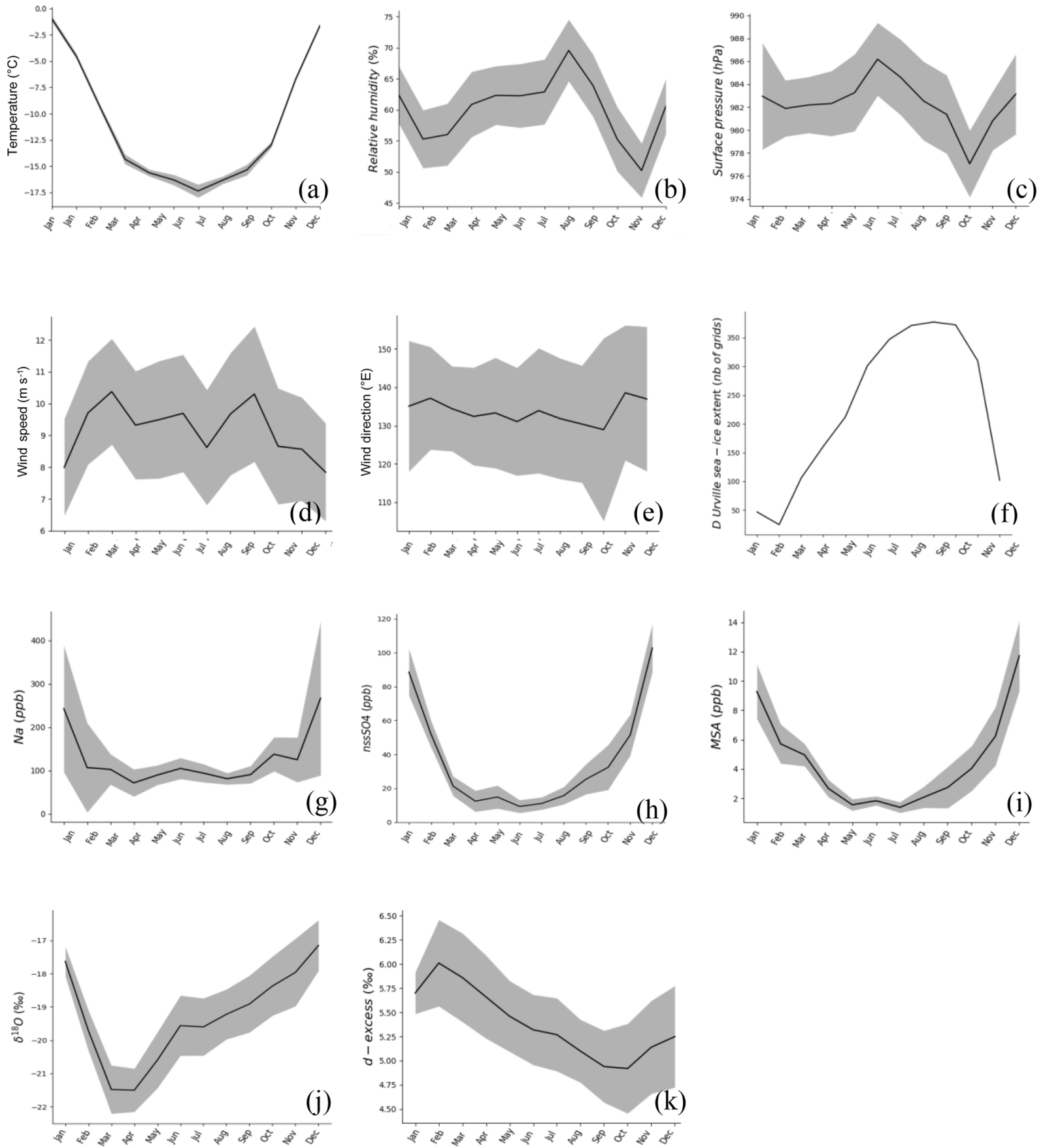

Figure 8. Mean seasonal cycles over the period 1998-2014. Meteorological observations are averaged from daily data, for near-surface temperature $\left(\mathbf{a},{ }^{\circ} \mathrm{C}\right)$, relative humidity $(\mathbf{b}, \mathrm{i} \%)$, surface pressure $(\mathbf{c}, \mathrm{hPa})$, wind speed $\left(\mathbf{d}, \mathrm{m} \mathrm{s}^{-1}\right)$, wind direction $\left(\mathbf{e},{ }^{\circ} \mathrm{E}\right)$, and local sea ice concentration, i.e. averaged over a $135-145^{\circ} \mathrm{E}$ ridge (f, \%). Seasonal cycles from ice core records are averaged from the resampled time series for $\mathrm{Na}(\mathbf{g}, \mathrm{ppb}), \mathrm{nssSO}_{4}(\mathbf{h}, \mathrm{ppb}), \operatorname{MSA}(\mathbf{i}, \mathrm{ppb}), \delta^{18} \mathrm{O}(\mathbf{j}, \% o)$, and $d$-excess $(\mathbf{k}, \%)$. The inter-annual standard deviation is highlighted with the grey shading.

with previous studies of aerosols and ice core signals (e.g. Preunkert et al., 2008). The $\delta^{18} \mathrm{O}_{\mathrm{TA}}$ seasonal cycle is surprisingly asymmetric (Fig. 8j), with a maximum in December and a minimum in April, thus not in phase with the seasonal cycles of local sea ice concentration (Fig. 8f) or DDU temperature (Fig. 8a). The mean $d$-excess TA $_{\mathrm{TA}}$ seasonal cycle (Fig. 8k) is marked by a maximum in February, 2 months after the $\delta^{18} \mathrm{O}_{\mathrm{TA}}$ maximum, and a minimum in October, 6 months after the $\delta^{18} \mathrm{O}_{\mathrm{TA}}$ minimum. We then calculated the mean of the isotopic seasonal amplitudes, preferentially to 
the amplitude of the mean seasonal cycle, due to the different timing of peaks from one year to another. The mean $\delta^{18} \mathrm{O}_{\mathrm{TA}}$ seasonal amplitude is $8.6 \% \circ \pm 2.1 \%$, more than 3 times higher than found in the $\mathrm{S} 1 \mathrm{C} 1$ ice core, and close to the DSSA mean $\delta^{18} \mathrm{O}$ seasonal cycle of $8.0 \%$ $\pm 2.8 \%$. The mean $d$-excess ${ }_{\mathrm{TA}}$ seasonal amplitude is $6.5 \% \circ \pm 2.8 \%$, close to the DSSA value of $5.3 \%$ $\pm 1.0 \%$. Compared with other precipitation and firn/ice core isotopic data from other regions of Antarctica (Table S7), the average seasonal amplitude obtained from TA $\delta^{18} \mathrm{O}$ is closest to the one obtained at KM, BI sites in Dronning Maud Land, and Vernadsky or Rothera on the peninsula but is much larger than identified from NUS 08-7 or WDC06A and significantly smaller than at Halley (by a factor of almost 2), Neumayer (a factor of 2.3), Dome C, or Dome F (a factor of $\sim 4$ ). In addition to DSSA, the average seasonal amplitude obtained from TA $d$ excess is also comparable to the one obtained in the $\mathrm{KM}$, BI, and IND25B5 firn cores in Dronning Maud Land but is systematically higher (by a factor higher than 3 ) than in precipitation datasets. This calls for systematic comparisons of $d$-excess seasonal amplitudes in precipitation and snow data.

Due to their common symmetric aspect, significant positive linear relationships emerge from the mean seasonal cycles of (i) temperature, $\mathrm{nssSO}_{4}$, and MSA $(r>0.93$ and $p<0.05$ ), (ii) $\mathrm{nssSO}_{4}$ and MSA $(r=0.97$ and $p<0.05$ ), (iii) $\mathrm{nssSO}_{4}$ and $\mathrm{Na}^{+}(r=0.93$ and $p<0.05)$, and finally (iv) $\delta^{18} \mathrm{O}$ with nssSO 4 ( $r=0.75$ and $\left.p<0.05\right)$. Due to the asymmetry of water stable isotope seasonal cycles, no linear relationship is detected between the seasonal cycles of DDU near-surface temperature, $\delta^{18} \mathrm{O}_{\mathrm{TA}}$, and $d$-excess $\mathrm{TA}$. Finally, the seasonal cycle of $d$-excess with all sea ice concentration indices (local, Indian, Amundsen, and regional), with correlation coefficients varying between -0.83 and -0.80 .

\subsubsection{Inter-annual variability of peaks}

Over the whole period covered by the TA firn core (19982014), the seasonal cycle of $\delta^{18} \mathrm{O}_{\mathrm{TA}}$ shows a large interannual variability (Table 6). $\delta^{18} \mathrm{O}_{\mathrm{TA}}$ maximum values occur primarily in summer ( $41 \%$ of the time) and winter $(41 \%)$ and more rarely in spring (12\%) and in autumn (6\%). The

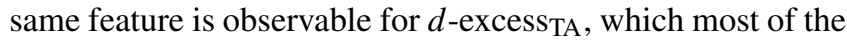
time has its maximum in summer $(38 \%)$ and winter $(43 \%)$ and more scarcely in spring $(6 \%)$ and in autumn (13\%).

In summary, the TA water stable isotope seasonal cycles display an asymmetry, with higher isotopic values in austral spring than in austral autumn. The $d$-excess $\mathrm{TA}_{\mathrm{TA}}$ seasonal cycle is anti-correlated with the reconstructed SMB. Finally, the TA isotopic seasonal cycles show a high inter-annual variability from one seasonal cycle to another one, with no recurrent pattern between those of $\delta^{18} \mathrm{O}_{\mathrm{TA}}$ and $d$-excess $\mathrm{TA}_{\mathrm{TA}}$.
Table 6. Fraction of annual maxima (\%) of $\delta^{18} \mathrm{O}$ and $d$-excess identified during each season: austral summer (DJF, i.e. from December to February), austral autumn (MAM, i.e. from March to May), austral winter (JJAS, i.e. from June to September), and austral spring (ON, i.e. from October to November) in the data over the period 1998-2014 and in the ECHAM5-wiso simulation (model) over the period 1998-2013. The analysis is based on resampled data (ice core) and monthly values (model).

\begin{tabular}{llrrrrr}
\hline Variable & Source & Period & DJF & MAM & JJAS & ON \\
\hline \multirow{2}{*}{$\delta^{18} \mathrm{O}$} & Data & $1998-2014$ & 41 & 6 & 41 & 12 \\
& Model & $1998-2013$ & 63 & 0 & 12 & 25 \\
\hline \multirow{2}{*}{$d$-excess } & Data & $1998-2014$ & 41 & 12 & 41 & 6 \\
& Model & $1998-2013$ & 0 & 69 & 31 & 0 \\
\hline
\end{tabular}

\subsection{Influence of synoptic weather on TA records: insights from ECHAM5-wiso simulation, ERA-Interim reanalyses, back trajectories, and modes of variability}

In order to explore the influence of the synoptic-scale weather on TA records, we explore outputs of ECHAM5wiso and back-trajectory calculations, driven by atmospheric reanalyses. None of the associated atmospheric simulations resolve local processes such as katabatic winds or sea breeze. We used the ECHAM5-wiso model outputs to explore the following questions: (i) do ECHAM5-wiso outputs show similarities with the corresponding observed variables for their inter-annual variability, trends, and remarkable years? (ii) What are the simulated seasonal cycles for $\delta^{18} \mathrm{O}$ and $d$ excess? (iii) What are the simulated relationships between local near-surface air temperature and $\delta^{18} \mathrm{O}$ and between $\delta^{18} \mathrm{O}$ and $d$-excess at the seasonal and inter-annual scales? (iv) Are there significant relationships between our isotopic records and the large-scale climatic variability?

\subsection{ECHAM5-wiso similarities with the corresponding observed variables}

For inter-annual variations, the annual means of DDU nearsurface temperature and the simulated $2 \mathrm{~m}$ temperature $\left(2 \mathrm{mT}_{\mathrm{ECH}}\right)$ are significantly correlated (slope of $0.50 \pm 0.14$, $r=0.67$, and $p<0.05$ ). This relationship is valid for all seasons. It is the strongest in winter (slope of $1.1 \pm 0.1{ }^{\circ} \mathrm{C}^{\circ} \mathrm{C}^{-1}$, $r=0.93$ and $p<0.05$ ) and the weakest in summer (slope of $0.98 \pm 0.3{ }^{\circ} \mathrm{C}^{\circ} \mathrm{C}^{-1}, r=0.69$, and $\left.p<0.05\right)$. There is no significant correlation between water stable isotope records from the TA and simulated by the ECHAM5-wiso, for either $\delta^{18} \mathrm{O}$ or $d$-excess. Finally, we found no significant trend in any model output over 1998-2014.

In terms of remarkable years, ECHAM5-wiso shows a low $\delta^{18} \mathrm{O}_{\mathrm{ECH}}$ mean value in 1998 and a high $d$-excess $\mathrm{ECH}_{\mathrm{EC}}$ mean value in 2007 (Fig. S4). Only the year 2007 is remarkable in both the data (low reconstructed SMB) and the model. 
We thus explored the model more deeply. The highest $d$ excess value was simulated 7 May (Table S8). When comparing from 6 to 8 May 2007, with daily averages over the period 1979-2014, the model simulates similar near-surface temperature but particularly low precipitation and wind components (zonal and meridional). Despite the small precipitation amount, the daily isotopic anomaly is sufficiently large to drive the annual anomaly (Fig. S5). The $d$-excess values higher than $30 \%$ o (threshold chosen as it corresponds to the maximum $d$-excess mean + standard deviation simulated by ECHAM5-wiso over Antarctica at the monthly scale; see Fig. S6) occur only four other times over 1998-2014. We nevertheless remain cautious with these values, which could be due to a numerical artefact.

$\mathrm{t} 2 \mathrm{~m}_{\mathrm{ECH}}-\delta^{18} \mathrm{O}_{\mathrm{ECH}}, \mathrm{SMB}_{\mathrm{ECH}}-d$-excess $\mathrm{ECH}_{\mathrm{EH}}$, and $\delta^{18} \mathrm{O}_{\mathrm{ECH}}{ }^{-}$ $d$-excess $s_{\mathrm{ECH}}$ relationships are not identified in ECHAM5wiso seasonal or annual outputs. Likewise, no significant relationship could be identified between $d$-excess TA $_{\text {and }}$ SMB simulated by ERA using both annual and seasonal values.

\subsubsection{Simulated seasonal cycles for $\delta^{18} \mathrm{O}$ and $d$-excess}

We now explore the seasonal variations in $\delta^{18} \mathrm{O}_{\mathrm{ECH}}$ and $d$ excess $_{\mathrm{ECH}}$ over the period of simulation (1998-2014, Table 6). The peaks in $t \delta^{18} \mathrm{O}_{\mathrm{ECH}}$ predominantly occur in spring and summer ( $25 \%$ and $63 \%$ respectively), while they only happen $12 \%$ of the time in winter and never in autumn. The $d$-excess ${ }_{\mathrm{ECH}}$ peaks most often in autumn $(69 \%)$ and secondarily in winter $(31 \%)$, but never during the other seasons. As a result, the model simulates more regular isotopic seasonal cycles with $\delta^{18} \mathrm{O}$ maxima during spring to summer seasons and $d$-excess maxima during autumn to winter seasons, than identified in the TA record.

\subsubsection{Relationships with the large-scale climatic variability}

The ERA-Interim outputs allow us to investigate whether the large-scale climatic variability influences the isotopic composition of Adélie Land precipitation recorded in the TA firn core. We looked at the simulated linear relationships between the TA isotopic records $\left(\delta^{18} \mathrm{O}_{\mathrm{TA}}\right.$ and $d$-excess $\left.\mathrm{TA}\right)$ with the ERA-Interim outputs (2mT, u10, v10, and z500, Sect. 2.2). Here we report only significant relationships with absolute correlation coefficients higher than 0.6. For $\delta^{18} \mathrm{O}_{\mathrm{TA}}$, we found a correlation with $2 \mathrm{mT}$ over the Antarctic plateau (Fig. 12a), as well as a correlation with v10 (Fig. 12b) along the westerly wind belt, at $\sim 55^{\circ} \mathrm{S}, 100^{\circ} \mathrm{E}$ and $\sim 55^{\circ} \mathrm{S}$, $130^{\circ} \mathrm{E}$ in the Indian Ocean and at $\sim 55^{\circ} \mathrm{S}, 10-50^{\circ} \mathrm{E}$ in the Atlantic Ocean, and a very little area on coastal Dronning Maud Land at $\sim 60^{\circ} \mathrm{S}, 30-40^{\circ} \mathrm{E}$. For $d$-excess $\mathrm{TA}$, we found a correlation with $2 \mathrm{mT}$ (Fig. 12c) toward the Lambert Glacier at $\sim 70-80^{\circ} \mathrm{S}, 30-40^{\circ} \mathrm{E}$ and an anti-correlation in the south of the peninsula at $\sim 55-65^{\circ} \mathrm{S}, 250-300^{\circ} \mathrm{E}$. Finally, we noted a correlation between $d$-excess $\mathrm{TA}_{\mathrm{TA}}$ and $\mathrm{u} 10$
(Fig. 12d) at a very narrow area of Dronning Maud Land at $\sim 80^{\circ} \mathrm{S}, 10-20^{\circ} \mathrm{E}$ and an anti-correlation on the westerly wind belt in the Atlantic Ocean at $\sim 55^{\circ} \mathrm{S}, 40-50^{\circ}$ E. No correlation is found with $\mathrm{z} 500, \delta^{18} \mathrm{O}_{\mathrm{TA}}$, or $d$-excess $\mathrm{TA}$.

Note that no significant relationship is obtained between the TA records and any mode of variability.

\subsubsection{Origin of air masses}

Finally, we used the HYSPLIT back-trajectory model to count the proportion (percentage) of air mass back trajectories, based on daily calculations over the period 19982014, and averaged at the annual and seasonal scale, from four different regions (Sect. 2.3): the plateau, the eastern Atlantic Ocean and the Indian Ocean (eastern sector), the Ross Sea sector (RSS), and the West Antarctic Ice Sheet with the Pacific Ocean and the western Atlantic Ocean (western sector), as displayed in Fig. 2. On average, the highest annual proportion of air masses comes from the eastern sector $(54.1 \pm 8.3 \%)$ and the East Antarctic plateau (32.5 \pm 4.9$)$, while a small proportion of air masses come from the western sector $(9.7 \pm 3.7 \%)$ and from the RSS $(3.6 \pm 1.3 \%)$. A $k$-mean clustering over the last points of the whole back trajectories indicate two main origins, in the Indian Ocean $\left(62.4^{\circ} \mathrm{S}, 131.7^{\circ} \mathrm{E}\right)$ and in the coastal West Antarctic Ice Sheet $\left(73.4^{\circ} \mathrm{S}, 227.5^{\circ} \mathrm{E}\right)$.

Inter-annual variations in back trajectories (Fig. 9b) reveal a positive trend for the fraction of air masses coming from the western sector (slope of $0.41 \pm 0.16 \% \mathrm{yr}^{-1}, r=0.55$, and $p<0.05$ ) and remarkable years: 1999 , which was identified as having a remarkable high $\delta^{18} \mathrm{O}$ value and low nssSO value in our TA records, is here associated with a minimum of back trajectories from the plateau, and the year 2011, which was associated with particularly high MSA in our TA record, shows a particularly low proportion of air masses coming from the eastern sector and a particularly high proportion of air masses coming from the Ross and western sectors.

The seasonal cycles of back trajectories per region are shown in Fig. 9c. The percentage of back trajectories coming from the plateau displays peaks in autumn and spring (March and November), those from the Ross Sea sector in winter and summer (January and June), those from the eastern sector in autumn and winter (May and August), and finally those from the western sector in spring (November). We note a significant linear correlation between the seasonal cycles of the percentage of $\delta^{18} \mathrm{O}$ and back trajectories coming from the Ross Sea sector $(r=0.68$ and $p<0.05)$ and from the western sector $(r=0.59$ and $p<0.05)$ and between the seasonal cycles of $d$-excess and the percentage of back trajectories coming from the western sector $(r=-0.67$ and $p<0.05)$.

Finally, we associated each daily back trajectory with daily precipitation $\delta^{18} \mathrm{O}$ and $d$-excess values simulated by ECHAM5-wiso in the precipitation and classified the time series for each variable by back-trajectory sectors. We then 

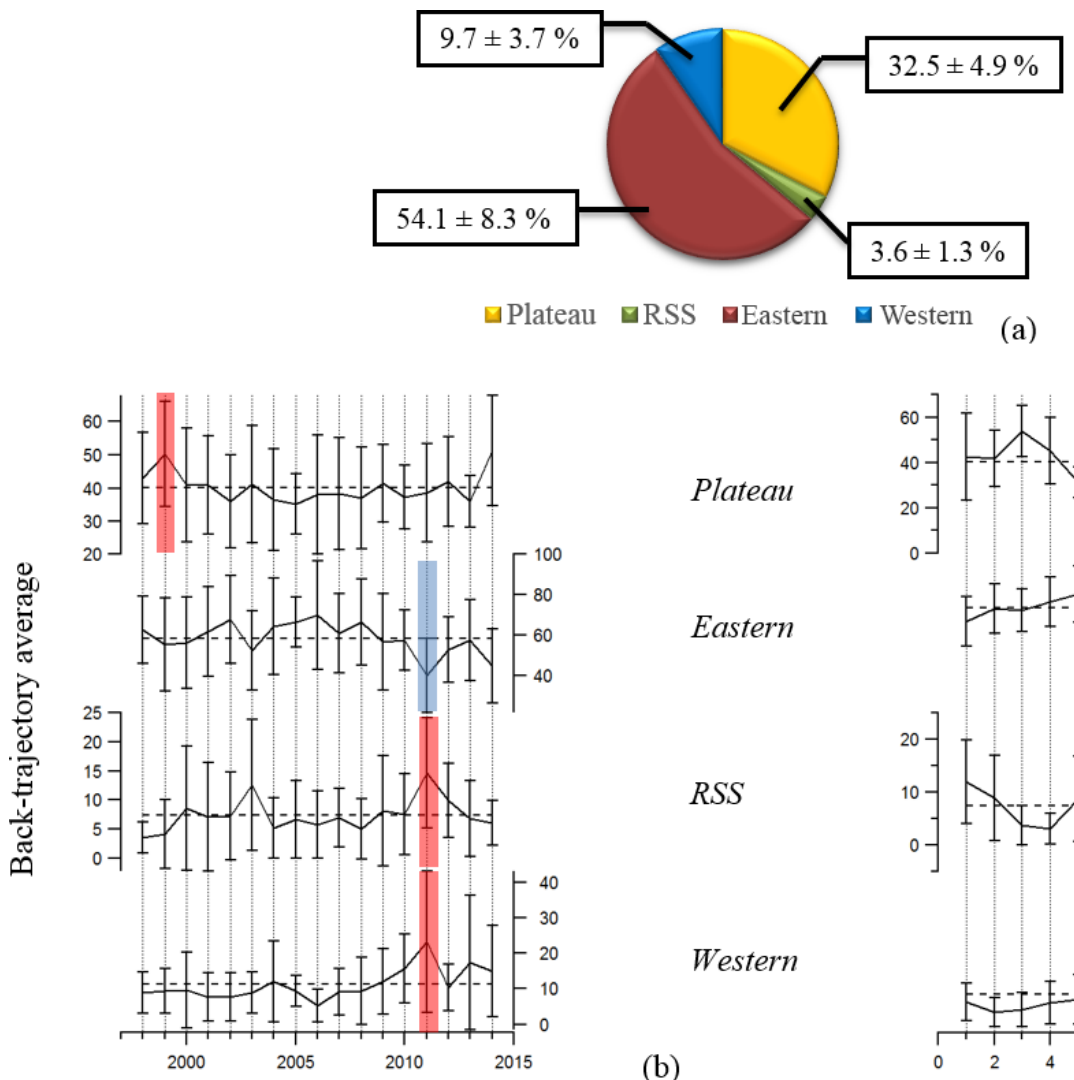

Plateau

$R S S$

Western

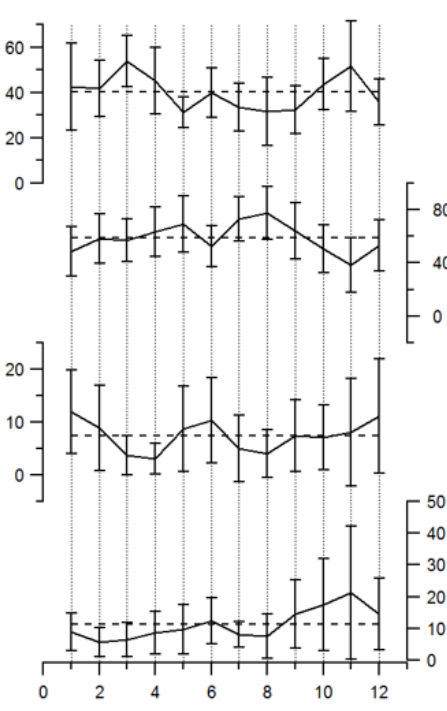

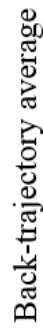

(c)

Figure 9. Results of daily back-trajectory calculations over the period 1998-2014 with (i) the percentage (\%) of the sum of back trajectories passing over each defined region: (i) the eastern sector $\left(0-66^{\circ} \mathrm{S}, 0-180^{\circ} \mathrm{E}\right)$, (ii) the plateau $\left(66-90^{\circ} \mathrm{S}, 0-180^{\circ} \mathrm{E}\right)$, (iii) the Ross Sea sector $\left(0-75^{\circ} \mathrm{S}, 180-240^{\circ} \mathrm{E}\right)$, and finally (iv) the western sector $\left(0-75^{\circ} \mathrm{S}, 180-240^{\circ} \mathrm{E}\right)$ and $\left(50-90^{\circ} \mathrm{S}, 240-360^{\circ} \mathrm{E}\right)$ (see Sect. 2.3), and with (ii) averages at the annual scale (b) and at the mean seasonal scale (c). In (b) and (c)) horizontal dashed lines correspond to the mean value and vertical solid lines to standard deviations. Remarkable years, i.e. associated with values deviating by at least 2 standard deviations from the climatological mean value, are highlighted with red shading (positive anomalies) or blue shading (negative anomalies).

computed the corresponding seasonal cycles (Fig. 10). The mean $\delta^{18} \mathrm{O}_{\mathrm{ECH}}$ value is slightly as high for air masses coming from the eastern sector $(-20.6 \%$ compared to $-21.9 \pm 0.2$ for the other sectors). The asymmetry in $\delta^{18} \mathrm{O}_{\mathrm{ECH}}$ is particularly well marked for air masses coming from the Ross Sea and western sectors, with peaks in August and September respectively (resulting in a winter amplitude more than twice higher compared to the eastern and plateau sectors) and corresponding to higher precipitation amounts during these months during the winter season. The $d$-excess mean seasonal cycles substantially differ by their amplitude: for air masses coming from the western sector, it is $11.8 \%$, with outstanding values in March and October (minima) and in May (higher than the mean plus 2 standard deviations), whereas it varies between $3.2 \%$ and $3.6 \%$ for the other sectors.

The back trajectory of 7 May 2007 (shown to be remarkable for simulated $d$-excess by ECHAM5-wiso) was identified as coming from the western sector, but those associated with the four other remarkable simulated $d$-excess (i.e. $>30 \%$ ) indicate air masses coming from the three other regions, and sometimes varying with the hour of the day (Fig. S6).

In summary, we found a mismatch between ECHAM5wiso outputs and the TA data for $d$-excess variations. There are no similarities for trends, for seasonal cycles, or for interannual isotopic variations. Similar to in the TA firn core, ECHAM5-wiso simulates no $\delta^{18} \mathrm{O}_{\mathrm{ECH}}-\mathrm{t} 2 \mathrm{~m}_{\mathrm{ECH}}$ correlation but no $d$-excess $\mathrm{ECH}-\delta^{18} \mathrm{O}_{\mathrm{ECH}}$. Both TA records and ECHAM5-wiso depict an unusual feature in 2007, with dry conditions and high $d$-excess values. The comparison between TA records and air mass back trajectories suggests that the asymmetry in the $\delta^{18} \mathrm{O}$ seasonal cycle is due to the precipitation of air masses coming from the western sector and that an increased occurrence of (rare) air masses coming from the western sector is associated with high $d$-excess values. 


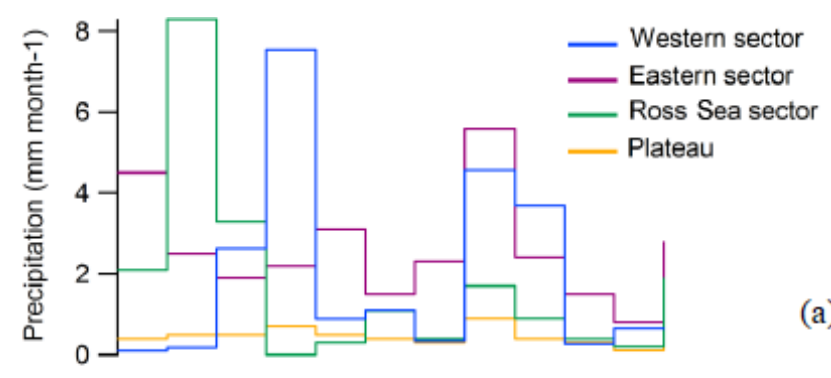

(a)
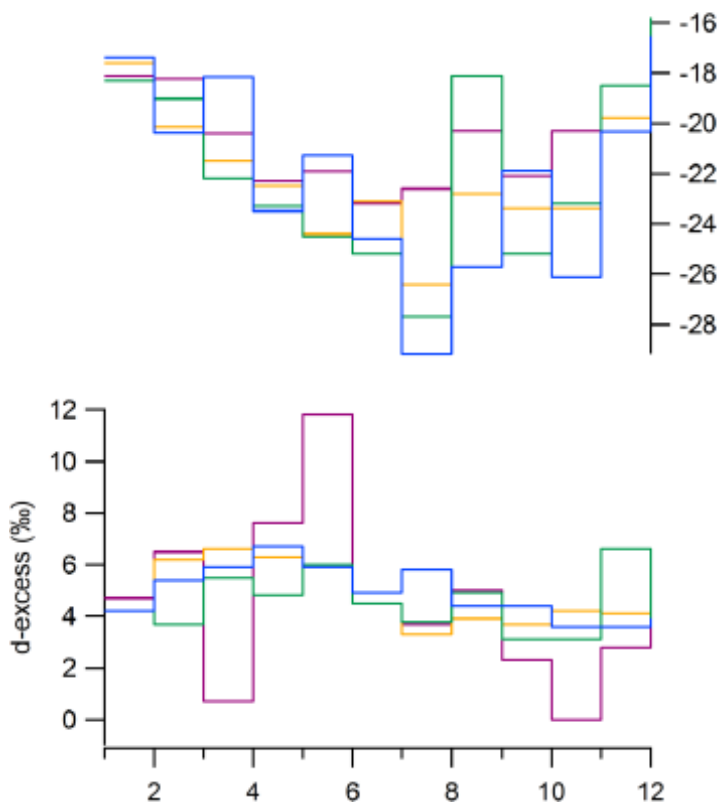

(c)

Figure 10. Seasonal cycles of precipitation $\left(\mathrm{mm} \mathrm{month}^{-1}\right)$. (a) $\delta^{18} \mathrm{O}(\%, \mathbf{b})$, and $d$-excess $(\%$, c) simulated by ECHAM5wiso by back-trajectory regions: (i) the eastern sector $\left(0-66^{\circ} \mathrm{S}, 0\right.$ $\left.180^{\circ} \mathrm{E}\right)$, (ii) the plateau $\left(66-90^{\circ} \mathrm{S}, 0-180^{\circ} \mathrm{E}\right)$, (iii) the Ross Sea sector $\left(0-75^{\circ} \mathrm{S}, 180-240^{\circ} \mathrm{E}\right)$, and finally (iv) the western sector $(0$ $\left.75^{\circ} \mathrm{S}, 180-240^{\circ} \mathrm{E}\right)$ and $\left(50-90^{\circ} \mathrm{S}, 240-360^{\circ} \mathrm{E}\right)$ (see Sect. 2.3).

\section{Discussion}

\subsection{SMB}

The estimated SMB of East Antarctica does not show a clear trend since 1900 (Favier et al., 2017). Recent studies (Altnau et al., 2015; Ekaykin et al., 2017; Vega et al., 2016) report negative SMB trends in coastal areas contrary to positive trends for the plateau. In particular, Thomas et al. (2017) report an unprecedented negative trend observed in Victoria Land for the last 50 years (1961-2010). For our study period (17 years for the TA record and the ECHAM5-wiso simulation), we observe no significant trend.

In Adélie Land, a quality controlled SMB dataset has been developed (Favier et al., 2013), but the drivers of SMB spatio-temporal variability remain unexplored (Favier et al., 2017). This is related to the challenges in monitoring (1) precipitation in windy areas, (2) sublimation of precipitating snowflakes (Grazioli et al., 2017b) in the katabatic flow, (3) and the amounts of surface erosion or deposition according to surface wind convergence or divergence, of drifting snow fluxes, and of sublimation of the drifting snow particles (Gallée et al., 2013; Amory et al., 2017, 2016). The low correlation (over 1998-2006) between TA192A annual accumulation and the first shallow ice core ( $\mathrm{S} 1 \mathrm{C} 1$; Goursaud et al., 2017), collected $14 \mathrm{~km}$ from TA192A site, demonstrates this complexity, even though this mismatch may be explained by age scale uncertainties. The $\mathrm{S} 1 \mathrm{C} 1$ reconstructed accumulation was also weakly correlated with stake data and model outputs, reflecting the random snow accumulation amounts due to the presence or absence of sastrugi and the potential occurrence of annual erosion at the S1C1 site (Fig. S7). Here, the TA accumulation record is highly correlated not only with the closest stake data, but also with the ECHAM5wiso model output over the period 2004-2014, showing the robustness of our reconstruction for this period. The fact that the TA record, the ECHAM5-wiso output for the corresponding grid point, and the $156 \mathrm{~km}$ stake area data are pairwise correlated $(0.79 \leq r \leq 0.90$ and $p<0.05)$ indicates that the TA firn core captures a $100 \mathrm{~km}$ scale regional signal. The differences between the local and regional SMB signal are (Fig. 3b) (i) a higher local SMB average compared to the regional SMB and (ii) the shift of the minimum peak of 2007 in the local signal (i.e. the TA firn core and the 19.2 stake data) to 2008 in the regional signal (see the 2007-2008 plateau in the $156 \mathrm{~km}$ network and the 2008 minimum value simulated by the ECHAM5-wiso model in Fig. 3b).

The anti-correlation between the $d$-excess $\mathrm{TA}_{\mathrm{TA}}$ and $\mathrm{SMB}_{\mathrm{TA}}$ shows the possibility of using water isotope firn core records from Adélie Land to complete the document of the SMB spatio-temporal variability. Dry air masses from the western sector may be associated with particularly high $d$-excess values. The remaining uncertainty in the dating and the extraction of a pure signal limited our investigation.

As a conclusion, the absence of similarity between the TA and the S1C1 accumulation reflects the uncertainty in the S1C1 dating resulting from the large spatial variability and from more frequent erosion processes occurring at the $\mathrm{S} 1 \mathrm{C} 1$ site. More ice core records within a $100 \mathrm{~km}$ area will allow the reduction of uncertainties in the interpretation of ice core signals, in particular in the link with the atmospheric variability.

\section{The $\delta^{18} \mathrm{O}$-temperature relationship in coastal Antarctic regions}

Several studies have shown that the annual $\delta^{18} \mathrm{O}$-temperature relationship is weak in coastal regions. As an example, over Dronning Maud Land, Isaksson and Karlén (1994) found a weaker correlation between $\delta^{18} \mathrm{O}$ records and Halley temperature for coastal ice cores, i.e. for sites below $1000 \mathrm{~m}$ a.s.l., with a correlation coefficient of 0.56 compared to a correlation coefficient of 0.91 for sites above 1000 a.s.l. More re- 
cently, Abram et al. (2013) reported a coefficient correlation of 0.52 for the relationship between $\delta^{18} \mathrm{O}$ recorded in the James Ross Island ice core (at a high of $1524 \mathrm{~m}$ a.s.l., with a mean reconstructed SMB of $63 \mathrm{~cm}$ w.e. $\mathrm{yr}^{-1}$ ) and the near-surface temperature measured at Esperanza station $(n=56$ and $p<0.05)$. In coastal West Antarctica, Thomas et al. (2013) also reported a significant but weak correlation between the $\delta^{18} \mathrm{O}$ recorded in an ice core drilled on the Bryan coast and the near-surface temperature simulated by ERA-Interim, over the period 1979-2009. Closer to Adélie Land, in Victoria Land, Bertler et al. (2011) found a correlation coefficient of 0.35 between the $\delta^{18} \mathrm{O}$ recorded in the Victoria Lower Glacier ice core (at a high of $626 \mathrm{~m}$ a.s.l.) and the summer near-surface temperature measured at Scott Base station $(n=30$ and $p<0.0005)$. In this study, we find no relationship between the DDU near-surface temperature and the $\delta^{18} \mathrm{O}_{\mathrm{TA}}$, based on annual averages. Similarly, no relationship had been identified in the S1C1 core (Goursaud et al., 2017) and was here not simulated by the ECHAM5wiso model.

Our study shows that changes in air mass trajectories (dynamics) may dominate over thermodynamical controls (condensation temperature) on the coastal Adélie Land $\delta^{18} \mathrm{O}$ signal, as shown by the asymmetry of the $\delta^{18} \mathrm{O}$ seasonal cycle recorded in the TA firn core (Sect. 3.4 and Fig. 8). The coupling of calculations of air mass back trajectories and ECHAM5-wiso outputs suggests that ${ }^{18} \mathrm{O}$ significant high values occurring during wintertime would be brought by air masses coming from the western sector (Sect. 3.5 and Fig. 10).

The $\delta^{18} \mathrm{O}$ measured in the ice of coastal Adélie Land may thus not allow the reconstruction of surface temperatures of this region. However, correlations between $\delta^{18} \mathrm{O}_{\mathrm{TA}}$ and the $2 \mathrm{~m}$ temperature by ERA-Interim over each grid point of Antarctica (Fig. 12a) show significant relationships over the plateau, confirmed by a significant correlation between annual $\delta^{18} \mathrm{O}_{\mathrm{TA}}$ and the near-surface temperature measured at Dome C over the period 1998-2014 (slope of 0.70\%॰ \pm $0.29 \% 0^{\circ} \mathrm{C}^{-1}, r=0.53, p<0.05$ ). These results support previous studies suggesting warm intrusions offshore of Dumont d'Urville towards Dome C (Naithani et al., 2002).

Finally, the significant linear relationships with the u10 wind component above the westerly wind belt and at some coastal Antarctic area (Fig. 12b) stress the influence of processes other than thermodynamic driving the isotopic composition of Adélie Land precipitations.

\subsection{Water stable isotope, a fingerprint of changes in air mass origins}

The mean $d$-excess $\mathrm{TA}$ is $5.4 \%_{\circ} \pm 1.0 \%$, close to the $4.7 \%$ \pm $0.4 \%$ value simulated by the ECHAM5-wiso model for the coastal Indian region defined in Goursaud et al. (2017, different definition than in this study), and the $5.2 \%$ o $\pm 0.6 \%$ value for the grid point corresponding to the TA drilling

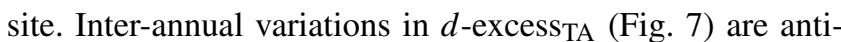
correlated with TA reconstructed SMB, a feature not depicted by ECHAM5-wiso.

\subsubsection{Main trajectories imprinted in the TA isotopic records}

We suggest that air masses associated with small or large precipitation amounts are associated with different trajectories and moisture sources: main air mass origins from the Indian Ocean. These maritime air masses, isotopically enriched, may transport water vapour to the plateau, as shown by the significant relationship between $\delta^{18} \mathrm{O}_{\mathrm{TA}}$ and the nearsurface temperature of the plateau, especially in winter. Rare dry air masses may also come from the western sector, with a signal preserved in $d$-excess. The following is evidence of the last point:

- the positive trends both for the TA $d$-excess and the percentage of air masses coming from the western sector;

- an anti-correlation between the seasonal cycles of the TA $d$-excess and percentages of air masses coming from the western sector;

- the high simulated $d$-excess amplitude simulated by ECHAM5-wiso for air masses coming from the western sector, reflecting outstanding values occurring in autumn and winter.

The particular case of 7 May 2007 with very high $d$-excess values simulated by ECHAM5-wiso corresponds to an air mass trajectory from the western sector.

As discussed earlier, the last item should be considered with caution as the four other remarkable $d$-excess values (i.e. higher than $30 \%$ ) simulated by ECHAM5-wiso are associated with air masses coming from other regions (Fig. S6) and also with the fact that such high values could be due to potential numerical artefacts.

Linear relationships between $d$-excessTA and ERAInterim outputs strengthen the link between the climate variability of western Antarctic and associated southern oceans, as we note an anti-correlation between $d$-excess $\mathrm{TA}_{\mathrm{T}}$ and the $2 \mathrm{mT}$ in the south of the peninsula, the Ellsworth region, and the Bellingshausen Sea $(r>0.6)$. We also note an anticorrelation between $d$-excess $\mathrm{TA}$ and the u10 wind component over the coastal Ross Sea sector, consistent with air mass trajectories coming from western Antarctica towards Adélie Land via the Ross Sea sector. These dry air masses might originate from the Amundsen and Bellingshausen seas (Emanuelsson et al., 2018; Winstrup et al., 2017) but cannot be directly linked to the Amundsen Sea cyclonic, as we obtain no significant relationship with the ASL center pressure indices. 


\subsubsection{Potential interaction with sea ice}

Noone and Simmonds (2004) have shown, thanks to climate modelling, that water stable isotopes were conditioned by changes in sea ice extent (a contraction in sea ice increases the local latent heat and temperature due to open water) but confirmed that a thorough understanding of the main mechanisms controlling the $d$-excess was still needed. Also, earlier studies have suggested the use of $d$-excess ice core records to reconstruct past sea ice extent (e.g. Sinclair et al., 2014). Although we find a significant correlation between the $d$-excess TA $_{\text {and }}$ and the Dumont d'Urville summer sea ice extent (Sect. 3.3), a correlation map between the annual $d$-excess TA $_{\mathrm{TA}}$ and the summer sea ice concentration (Fig. S8) shows significant correlations with further sea ice areas (e.g. an anti-correlation in the Amundsen Sea and correlations in the Bellingshausen, Scotia, and Lazarev seas). We also noted a coincidence between the sign of the correlation of the relationship between the $d$-excess TA $_{\text {and }}$ ane sea ice concentration and the sea ice extent trend over the period 1998-2014 (Fig. S9), especially positive correlations (negative) associated with positive sea ice concentration trends. These findings call for mechanistic studies to understand the different processes behind $d$-excess associated with each air mass origin.

As we suggested a particular $d$-excess signature in the TA firn core, associated with air masses coming from the western sector, we tested the possibility for the $d$-excess TA $_{\text {T }}$ to imprint changes in the Ross polynya. We thus estimated it, by counting the annual sea ice concentration over the polygon (60$70^{\circ} \mathrm{S} ; 150-210^{\circ} \mathrm{E}$ ), to be lower than $15 \%$. But we find no significant correlation between this estimated Ross polynya and the $d$-excess ${ }_{\mathrm{TA}}$ over the period 1998-2014.

\subsection{The $\delta^{18} \mathrm{O}-\delta \mathrm{D}$ relationship}

Earlier studies showed empirically that the relationship between $d$-excess and $\delta^{18} \mathrm{O}$, and mainly the phase lag between signals within the seasonal cycle, may indicate variations in the origin of the moisture source. This phage lag was shown to be of 3-4 months over coastal regions such as Law Dome (Masson-Delmotte et al., 2003), Dronning Maud Land (Vega et al., 2016) and the Ross Sea sector (Sinclair et al., 2014). By contrast, most studies identified an anti-phase over the East Antarctic plateau (e.g. Landais et al., 2012; Ciais et al., 1995), and at D47, situated close to the TA drilling site (Ciais et al., 1995).

We thus focus on the outcome of the running linear regression between $d$-excess $\mathrm{TA}_{\mathrm{TA}}$ and $\delta^{18} \mathrm{O}_{\mathrm{TA}}$ over 10 points all along the core (Fig. 11). We focus on the periods $(53.3 \%)$ when a significant linear relationship is identified (i.e. $p<$ $0.05)$. The time-averaged correlation coefficient is $0.71 \pm$ 0.45 , which is consistent with the results obtained from the annual averages (varying from 0.51 in autumn to 0.75 in spring, Sect. 3.3). The time-averaged slope is $0.83 \% \%^{-1} \pm$
$0.83 \% \%_{0}^{-1}$. These positive values prevail for $91.5 \%$ of the significant linear regressions. However, we observe remarkable deviations from this overall relationship. In particular, linear regressions within the year 2007 show slopes lower than the time averaged minus 2 standard deviations (with a minimum value of $-1.46 \% \%^{-1}$ ), and others within the year 2011 show surprisingly very high slopes up to $6.9 \% \% \%^{-1}$. The years 2007 and 2011 were also previously

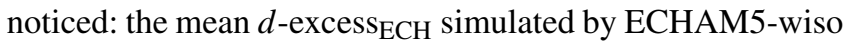
for the year 2007 was shown to be driven by the high value occurring on 7 May, associated with air masses coming from the western sector. The year 2011 is associated with a minimum of annual back-trajectory percentages from the eastern sector and maxima of back trajectories from the Ross Sea and the western sector. As a result, the $\delta^{18} \mathrm{O}-d$-excess relationship may be a fingerprint of changes in air mass origins, and particularly of the occurrence of precipitation of air masses coming from the western sector.

We undertook the same exercise with outputs of the ECHAM5-wiso model (Fig. S10), where only $19.2 \%$ of the simulated linear regressions are significant (i.e. $p<0.05$ ). All significant relationships have negative correlation coefficients and slopes of time-averaged values $-0.72 \% \%^{-1} \pm$ $0.25 \% \% \%^{-1}$ and $-0.39 \% \circ \%^{-1} \pm 0.23 \% \%^{-1}$ respectively (this is consistent with the annual means, Sect. 3.4). Moreover, these significant relationships do not occur during the remarkable years 2007 and 2011 identified in the TA firn core.

As a result, we propose that remarkable anomalies in $d$ excess $/ \delta^{18} \mathrm{O}$ running linear relationships provide an isotopic fingerprint associated with changes in dominant air mass trajectories. But a more comprehensive mechanistic study would be necessary to quantify the fractionation processes associated with different moisture source and transport characteristics.

\subsection{Limits associated with model-data isotopic comparisons}

We note a mismatch between ECHAM5-wiso outputs and the data (Sect. 3.5 and Fig. S4). This could be related to (i) postdeposition processes associated with wind scoring or snow metamorphism not resolved in ECHAM5-wiso, (ii) the key role of very local atmospheric circulation effects related to katabatic wind processes, not resolved in large-scale atmospheric reanalyses and simulations, (iii) or the difficulties of ECHAM5-wiso to resolve the processes associated with the ocean boundary vapour $d$-excess, a mismatch already identified in the Arctic (Steen-Larsen et al., 2017).

The first issue is related with the robustness of records from a single coastal firn core. Several studies have evidenced signal-to-noise limits (e.g. Mulvaney et al., 2002; Graf et al., 2002). Given the high SMB estimated from TA, diffusion effects can be ignored (Frezzotti et al., 2007), and the estimated inter-annual variations in TA SMB are closely 


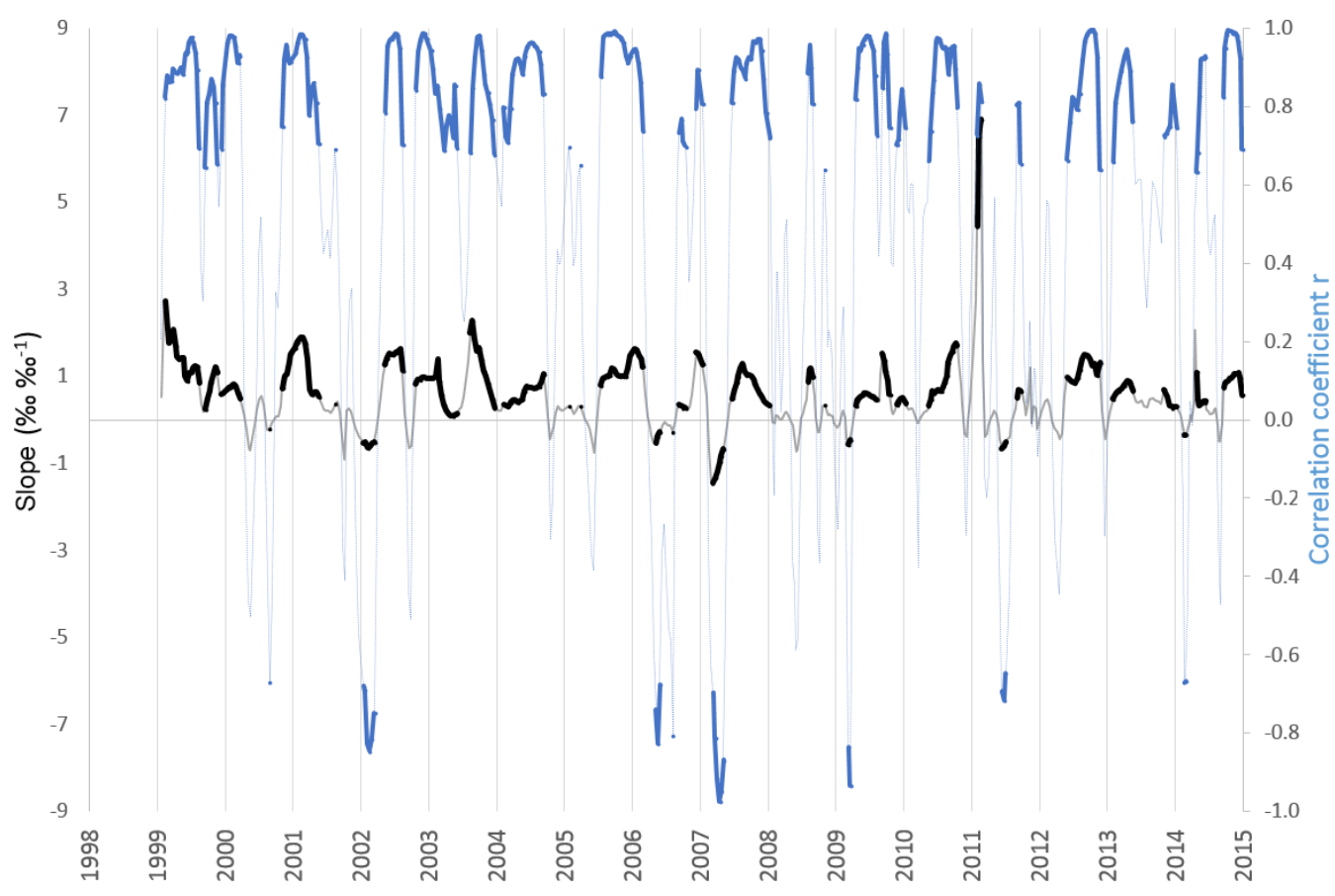

Figure 11. The 10-point running slope $\left(\% \circ \% o^{-1}\right)$ and running correlation coefficient calculated between $d$-excess versus $\delta^{18} \mathrm{O}$ calculated from the raw data of TA192A. Significant results are indicated by thick lines $(p<0.05)$. The date associated with the results corresponds to the first point of the regression calculation (applied to 10 points).

correlated not only with stake data closest to the drilling site, but also with the $156 \mathrm{~km}$ network stake data and to precipitation from the corresponding grid point of ECHAM5-wiso within a $100 \mathrm{~km} \times 100 \mathrm{~km}$ area. This finding supports an interpretation of the TA record being representative of a regional SBM signal (100 km scale). However, we cannot draw any conclusion of the signal-to-noise aspects of the water stable isotope records, given the lack of coherency between the inter-annual variability in the TA and $\mathrm{S} 1 \mathrm{C} 1 \delta^{18} \mathrm{O}$ records for the few years of overlap (unfortunately, there are no striking features during the common period records, which makes it challenging to match the isotope records) and the lack of any other $d$-excess record within hundreds of kilometers.

The second source of uncertainty lies in the mismatch between inter-annual variations from coastal Adélie Land meteorological observations and the TA records, with ECHAM5wiso outputs. For instance, we only see high correlation for the surface air temperature inter-annual variations for winter and weak correlation for wind speed in spring and summer. These findings suggest limitations in the skills of either atmospheric reanalyses or the ECHAM5-wiso model to correctly capture the processes responsible for local climate variability. We had previously reported the capability of ECHAM5wiso to correctly simulate observed large-scale features of water stable isotopes and SMB across Antarctica, for spatiotemporal patterns identified from datasets spanning the last decades such as mean values, amplitudes and phases of mean seasonal cycles, amplitude of inter-annual variance, strength of isotope-temperature relationships, and $d$-excess versus $\delta^{18} \mathrm{O}$ relationships) (Goursaud et al., 2017). We thus highlight here specific challenges related to the Antarctic coastline, where local processes associated with katabatic winds, open water (e.g. polynya), and local boundary layer processes (e.g. snow drift) may affect isotopic records without being resolved at the resolution of reanalyses and ECHAM5wiso simulation.

Our study therefore depicts limited understanding of the drivers of seasonal and inter-annual variability in the coastal Adélie Land hydrological cycle and thus calls for more isotopic measurements (from ice cores, snow precipitation, and water vapour) in Adélie Land to reduce uncertainties.

\subsection{Chemistry}

We compare the chemical concentrations recorded in the TA firn core with the S1C1 core (Goursaud et al., 2017), for their common period (1998-2006). The mean concentrations are slightly lower for the TA than the S1C1 firn core from $30 \%$ for $\mathrm{Na}^{+}$to $50 \%$ for MSA (Table S9). This decrease with the increasing distance from the coast (or elevation above sea level) is consistent with atmospheric studies showing a decrease in levels from the coast to the plateau for sea salt (Legrand et al., 2017b) and sulfur aerosols (Legrand et al., 2017a). No significant linear regression emerges from any chemical species, highlighting a high spatial variability and/or the uncertainty in the dating of the S1C1 firn core. 


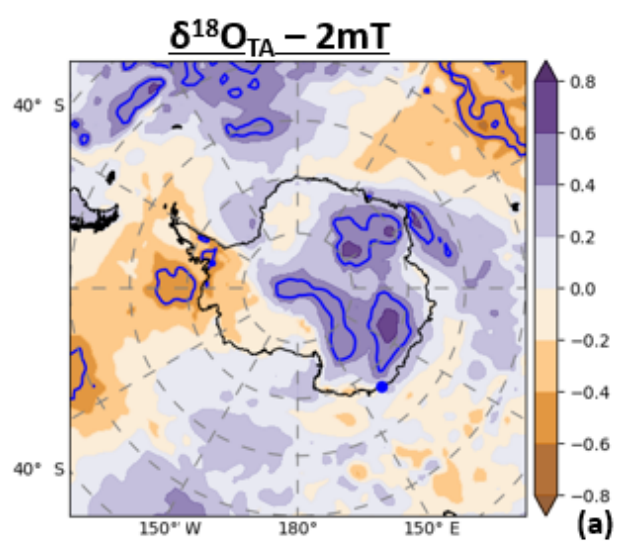

d-excess $_{\mathrm{TA}}-2 \mathrm{mT}$

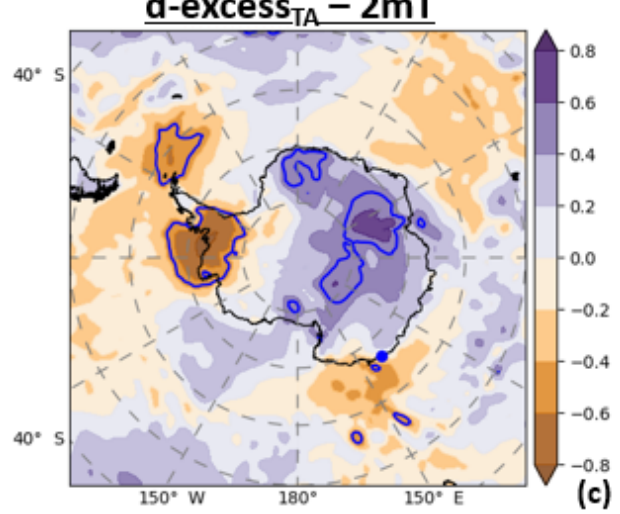

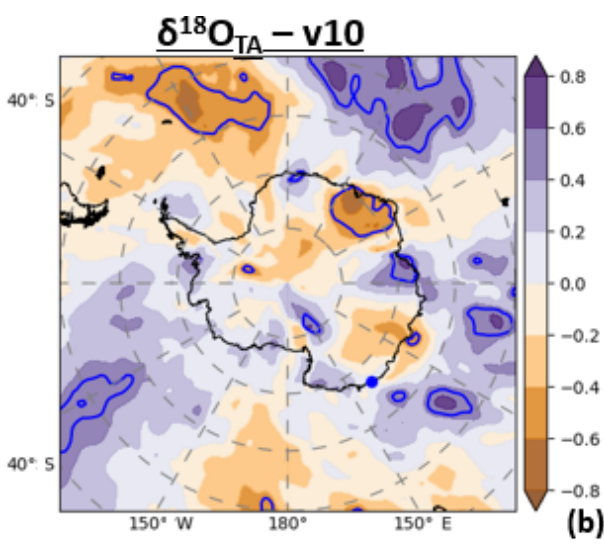

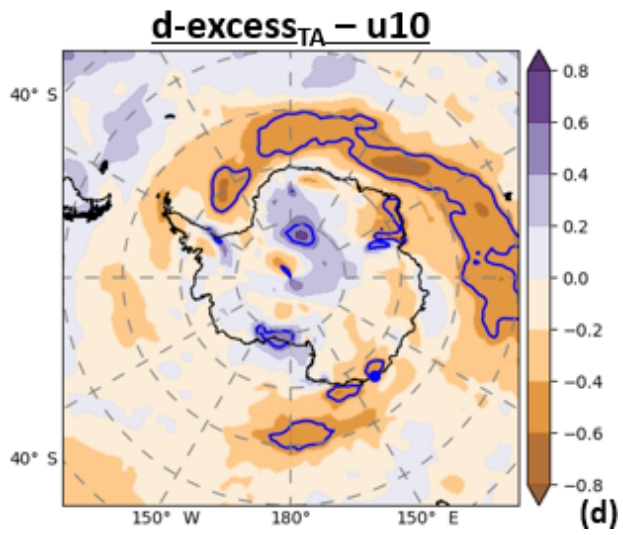

Figure 12. Coefficient correlation between the TA isotopic records and ERA-Interim reanalyses, (a) between $\delta^{18} \mathrm{O}_{\mathrm{TA}}$ and the $2 \mathrm{~m}$ temperature, (b) between $\delta^{18} \mathrm{O}_{\mathrm{TA}}$ and the $10 \mathrm{~m} v$ wind component, (c) between $d$-excess $\mathrm{TA}$ and the $2 \mathrm{~m}$ temperature, and finally (d) between $d$-excess TA and the $10 \mathrm{~m} u$ wind component. The blue point locates the TA192A drilling site, and the blue lines contour the significant correlations.

Finally, we initially processed chemical measurements in our firn core to support the isotopic records not only for dating, but also to identify air mass origins, making the hypothesis of three possible cases. (i) Air masses formed near the sea ice margin may be associated with relatively high $d$-excess and $\delta^{18} \mathrm{O}$ values, due to respectively a high kinetic fractionation due to evaporation under low humidity levels and limited distillation effects. Such a configuration should be associated with low sea-salt concentrations due to the presence of the sea ice, as shown by atmospheric studies (Legrand et al., 2016). (ii) In contrast, vapour formed over the ocean in the absence of sea ice may be associated with high $\delta^{18} \mathrm{O}$ values, low $d$-excess, and high sea-salt concentrations. (iii) Finally, air masses from central Antarctica may be associated with depleted $\delta^{18} \mathrm{O}$ values and high $d$-excess, while air masses from ocean regions may lead to intermediate $\delta^{18} \mathrm{O}$ and $d$ excess values, due to distillation effects, and evaporation under relatively humid conditions, but with low sea-salt concentrations.

The period from December 2003 to February 2004, associated with $\mathrm{Na}^{+}$values higher than the mean plus 5 standard deviations, probably caused by marine advections, is not dis- tinguishable in the isotopic records. None of the three aforementioned cases were systematically observed.

To make it short, taking into account the definition of only summer observations does not alter our results. The sea-salt and sulfur concentrations measured along the TA records are slightly lower compared to the S1C1 firn core, consistent with the coast-to-plateau depletion previously observed in atmospheric measurement. Unfortunately, we could not use the sea-salt measurements to support our hypotheses regarding the air mass origins associated with isotopic compositions.

\section{Conclusions and perspectives}

In this study, we report the analysis of the first highly resolved firn core drilled in Adélie Land covering the very recent period 1998-2014, with a sub-annual resolution. The chronology was based on chemical tracers $\left(\mathrm{Na}, \mathrm{nssSO}_{4}\right.$, and MSA) and adjusted by 1 year based on stake area information. Three $\delta^{18} \mathrm{O}$ peaks found no counterparts in the chemical records. The high estimated SMB rate of $74.1 \pm$ $14.1 \mathrm{~cm}$ w.e. $\mathrm{yr}^{-1}$ limits the effects of diffusion and ensures that records with sub-annual resolution are preserved 
(e.g. Johnsen, 1977). The good consistency of the estimated annual SMB variations with observations on stakes reflects that high accumulation amounts are needed to ensure that small-scale SMB random variability caused by presence of sastrugi, dunes, and barchans is negligible when compared to the mean accumulation value. This condition allows us to avoid the erosion of seasonal or annual layers, which would lead to removal of the annual cycle of the recorded signal. For this reason, obtaining long-term observations on distributed stake networks around a drilling site or ground-penetrating radar data is crucial to accurately select a drilling site, by retrieving the location of mesoscale accumulation maxima and by rejecting zones with potential erosion.

Using an updated database of Antarctic surface snow isotopes, we showed that not only $\delta^{18} \mathrm{O}_{\mathrm{TA}}$ but also $d$-excess mean values are in line with the range of coastal values in other locations.

Neither in the TA-DDU dataset nor in the ECHAM5-wiso output do we see any significant relationship between interannual variations in $\delta^{18} \mathrm{O}$ and local surface air temperature. The anti-correlation between annual reconstructed $\mathrm{SMB}_{\mathrm{TA}}$ and $d$-excess TA $_{\text {A }}$ leads us to suggest that changes in largescale atmospheric transport could lead to an explanation for this feature. In particular back-trajectory simulations from HYSPLIT and atmospheric outputs from ECHAM5-wiso at the seasonal cycle show the occurrence of air masses coming from the western sector during autumn and winter, corresponding to high simulated $d$-excess values. Also, the identification of remarkable years in both back-trajectory percentages and the relationships between $d$-excess and $\delta^{18} \mathrm{O}$ also leads us to evidence a potential in the $d$-excess- $\delta^{18} \mathrm{O}$ to identify remarkable features in moisture transport.

We cannot explain at this stage the observed positive trends in the $d$-excess $\mathrm{TA}$. We suggest that an improved understanding of the drivers of moisture transport towards coastal Adélie Land can benefit from the interpretation of water stable isotope tracers, especially $d$-excess, through mechanistic studies and the exploration of global atmospheric models. Ways forward include a better documentation of the spatiotemporal variability in SMB and water stable isotopes using a matrix of coastal firn core records spanning longer periods over the last decades (17 points being small to assess linear relationships and record climate shifts, e.g. the IPO shift occurring in 1998; Turner et al., 2016); a better documentation of the relationships between precipitation and ice core records through the monitoring of the isotopic composition of surface vapour and precipitation snow and firn (Casado et al., 2016; Ritter et al., 2016); and the implementation of water stable isotopes in regional models resolving the key missing processes linked for instance with katabatic winds, boundary layer processes, and wind drift (Gallée et al., 2013).
Data availability. The TA192A isotope and chemical firn core records were archived in the PANGAEA data library at https://doi.org/10.1594/PANGAEA.896623 (Goursaud et al., 2018b).

Supplement. The supplement related to this article is available online at: https://doi.org/10.5194/tc-13-1297-2019-supplement.

Author contributions. ML and SP sampled the ice core and monitored the chemical measurements. BM monitored the water stable measurements. VF provided the accumulation data from the stake measurements. MW performed the ECHAM5-wiso simulations. SG dated the firn core, analysed the data, and wrote the paper with contributions from all co-authors.

Competing interests. The authors declare that they have no conflict of interest.

Acknowledgements. This study has been supported by the ASUMA project supported by the ANR (Agence Nationale de la Recherche, project no. ANR-14-CE01-0001), which funded the $\mathrm{PhD}$ grant of Sentia Goursaud and the publication costs of this paper. The authors also acknowledge the support from Institut Paul-Emile Victor (IPEV) for the surface mass balance observatory in Antarctica (GLACIOCLIM-SAMBA). This project also received support from the Investissements d'Avenir project EquipEX "Equipement d'Excellence" CLIMCOR (ANR-11-EQPX-0009-CLIMCOR).

Review statement. This paper was edited by Becky Alexander and reviewed by Elizabeth Thomas, Daniel Emanuelsson, and one anonymous referee.

\section{References}

Abram, N. J., Mulvaney, R., Wolff, E. W., Triest, J., Kipfstuhl, S., Trusel, L. D., Vimeux, F., Fleet, L., and Arrowsmith, C.: Acceleration of snow melt in an Antarctic Peninsula ice core during the twentieth century, Nat. Geosci., 6, 404-411, https://doi.org/10.1038/ngeo1787, 2013.

Adolphs, U. and Wendler, G.: A pilot study on the interactions between katabatic winds and polynyas at the Adélie Coast, eastern Antarctica, Antarctic Sci., 7, 307-314, https://doi.org/10.1017/S0954102095000423, 1995.

Agosta, C., Favier, V., Genthon, C., Gallée, H., Krinner, G., Lenaerts, J. T., and van den Broeke, M. R.: A 40-year accumulation dataset for Adelie Land, Antarctica and its application for model validation, Clim. Dynam., 38, 75-86, https://doi.org/10.1007/s00382-011-1103-4, 2012.

Altnau, S., Schlosser, E., Isaksson, E., and Divine, D.: Climatic signals from 76 shallow firn cores in Dronning Maud Land, East Antarctica, The Cryosphere, 9, 925-944, https://doi.org/10.5194/tc-9-925-2015, 2015. 
Amory, C., Naaim-Bouvet, F., Gallée, H., and Vignon, E.: Brief communication: Two well-marked cases of aerodynamic adjustment of sastrugi, The Cryosphere, 10, 743-750, https://doi.org/10.5194/tc-10-743-2016, 2016.

Amory, C., Gallée, H., Naaim-Bouvet, F., Favier, V., Vignon, E., Picard, G., Trouvilliez, A., Piard, L., Genthon, C., and Bellot, H.: Seasonal variations in drag coefficient over a sastrugicovered snowfield in coastal East Antarctica, Bound.-Lay. Meteorol., 164, 107-133, https://doi.org/10.1007/s10546-017-0242-5, 2017.

Bertler, N., Mayewski, P., and Carter, L.: Cold conditions in Antarctica during the Little Ice Age - Implications for abrupt climate change mechanisms, Earth Planet. Sci. Lett., 308, 41-51, 2011.

Bertler, N. A. N., Conway, H., Dahl-Jensen, D., Emanuelsson, D. B., Winstrup, M., Vallelonga, P. T., Lee, J. E., Brook, E. J., Severinghaus, J. P., Fudge, T. J., Keller, E. D., Baisden, W. T., Hindmarsh, R. C. A., Neff, P. D., Blunier, T., Edwards, R., Mayewski, P. A., Kipfstuhl, S., Buizert, C., Canessa, S., Dadic, R., Kjær, H. A., Kurbatov, A., Zhang, D., Waddington, E. D., Baccolo, G., Beers, T., Brightley, H. J., Carter, L., Clemens-Sewall, D., Ciobanu, V. G., Delmonte, B., Eling, L., Ellis, A., Ganesh, S., Golledge, N. R., Haines, S., Handley, M., Hawley, R. L., Hogan, C. M., Johnson, K. M., Korotkikh, E., Lowry, D. P., Mandeno, D., McKay, R. M., Menking, J. A., Naish, T. R., Noerling, C., Ollive, A., Orsi, A., Proemse, B. C., Pyne, A. R., Pyne, R. L., Renwick, J., Scherer, R. P., Semper, S., Simonsen, M., Sneed, S. B., Steig, E. J., Tuohy, A., Venugopal, A. U., Valero-Delgado, F., Venkatesh, J., Wang, F., Wang, S., Winski, D. A., Winton, V. H. L., Whiteford, A., Xiao, C., Yang, J., and Zhang, X.: The Ross Sea Dipole - temperature, snow accumulation and sea ice variability in the Ross Sea region, Antarctica, over the past 2700 years, Clim. Past, 14, 193-214, https://doi.org/10.5194/cp-14193-2018, 2018.

Bonne, J. L., Steen-Larsen, H. C., Risi, C., Werner, M., Sodemann, H., Lacour, J. L., Fettweis, X., Cesana, G., Delmotte, M., and Cattani, O.: The summer 2012 Greenland heat wave: In situ and remote sensing observations of water vapor isotopic composition during an atmospheric river event, J. Geophys. Res.-Atmos., 120, 2970-2989, 2015.

Bouchard, A., Rabier, F., Guidard, V., and Karbou, F.: Enhancements of satellite data assimilation over Antarctica, Mon. Weather Rev., 138, 2149-2173, 2010.

Bromwich, D. H. and Fogt, R. L.: Strong trends in the skill of the ERA-40 and NCEP-NCAR reanalyses in the high and midlatitudes of the Southern Hemisphere, 1958-2001, J. Climate, 17, 4603-4619, 2004.

Bromwich, D. H., Fogt, R. L., Hodges, K. I., and Walsh, J. E.: A tropospheric assessment of the ERA-40, NCEP, and JRA-25 global reanalyses in the polar regions, J. Geophys. Res.-Atmos., 112, 1-21, https://doi.org/10.1029/2006JD007859, 2007.

Bromwich, D. H., Nicolas, J. P., and Monaghan, A. J.: An assessment of precipitation changes over Antarctica and the Southern Ocean since 1989 in contemporary global reanalyses, J. Climate, 24, 4189-4209, 2011.

Caiazzo, L., Becagli, S., Frosini, D., Giardi, F., Severi, M., Traversi, R., and Udisti, R.: Spatial and temporal variability of snow chemical composition and accumulation rate at Talos Dome site (East Antarctica), Sci. Total Environ., 550, 418-430, 2016.
Casado, M., Landais, A., Masson-Delmotte, V., Genthon, C., Kerstel, E., Kassi, S., Arnaud, L., Picard, G., Prie, F., Cattani, O., Steen-Larsen, H.-C., Vignon, E., and Cermak, P.: Continuous measurements of isotopic composition of water vapour on the East Antarctic Plateau, Atmos. Chem. Phys., 16, 8521-8538, https://doi.org/10.5194/acp-16-8521-2016, 2016.

Cavalieri, D., Parkinson, C., Gloersen, P., and Zwally, H.: Sea ice concentrations from Nimbus-7 SMMR and DMSP SSM/I passive microwave data, National Snow and Ice Data Center, Boulder, Colorado, USA, 1996

Church, J. A., Clark, P. U., Cazenave, A., Gregory, J. M., Jevrejeva, S., Levermann, A., Merrifield, M. A., Milne, G. A., Nerem, R. S., and Nunn, P. D.: Sea level change, PM Cambridge University Press, 2013.

Ciais, P., White, J., Jouzel, J., and Petit, J.: The origin of presentday Antarctic precipitation from surface snow deuterium excess data, J. Geophys. Res.-Atmos., 100, 18917-18927, 1995.

Comiso, J. C., Gersten, R. A., Stock, L. V., Turner, J., Perez, G. J., and Cho, K.: Positive trend in the Antarctic sea ice cover and associated changes in surface temperature, J. Climate, 30, 22512267, 2017.

Dansgaard, W.: Stable isotopes in precipitation, Tellus, 16, 436468, https://doi.org/10.3402/tellusa.v16i4.8993, 1964

Dee, D., Uppala, S., Simmons, A., Berrisford, P., Poli, P., Kobayashi, S., Andrae, U., Balmaseda, M., Balsamo, G., and Bauer, P.: The ERA-Interim reanalysis: Configuration and performance of the data assimilation system, Q. J. Roy. Meteorol. Soc., 137, 553-597, 2011a.

Dee, D. P., Uppala, S., Simmons, A., Berrisford, P., Poli, P., Kobayashi, S., Andrae, U., Balmaseda, M., Balsamo, G., and Bauer, P.: The ERA-Interim reanalysis: Configuration and performance of the data assimilation system, Q. J. Roy. Meteorol. Soc., 137, 553-597, 2011b.

Delmotte, M., Masson, V., Jouzel, J., and Morgan, V. I.: A seasonal deuterium excess signal at Law Dome, coastal eastern Antarctica: a southern ocean signature, J. Geophys. Res.-Atmos., 105, 7187-7197, 2000.

Dittmann, A., Schlosser, E., Masson-Delmotte, V., Powers, J. G., Manning, K. W., Werner, M., and Fujita, K.: Precipitation regime and stable isotopes at Dome Fuji, East Antarctica, Atmos. Chem. Phys., 16, 6883-6900, https://doi.org/10.5194/acp16-6883-2016, 2016.

Draxler, R. R. and Hess, G.: An overview of the HYSPLIT_4 modelling system for trajectories, Aust. Meteorol. Magazine, 47, 295-308, 1998.

Eisen, O., Frezzotti, M., Genthon, C., Isaksson, E., Magand, O., van den Broeke, M. R., Dixon, D. A., Ekaykin, A., Holmlund, P., and Kameda, T.: Ground-based measurements of spatial and temporal variability of snow accumulation in East Antarctica, Rev. Geophys., 46, 1-39, 2008.

Ekaykin, A. A., Vladimirova, D. O., Lipenkov, V. Y., and MassonDelmotte, V.: Climatic variability in Princess Elizabeth Land (East Antarctica) over the last 350 years, Clim. Past, 13, 61-71, https://doi.org/10.5194/cp-13-61-2017, 2017.

Emanuelsson, B. D., Bertler, N. A., Neff, P. D., Renwick, J. A., Markle, B. R., Baisden, W. T., and Keller, E. D.: The role of Amundsen-Bellingshausen Sea anticyclonic circulation in forcing marine air intrusions into West Antarctica, Clim. Dynam., 51, 3579-3596, 1-18, 2018. 
Favier, V., Agosta, C., Parouty, S., Durand, G., Delaygue, G., Gallée, H., Drouet, A.-S., Trouvilliez, A., and Krinner, G.: An updated and quality controlled surface mass balance dataset for Antarctica, The Cryosphere, 7, 583-597, https://doi.org/10.5194/tc-7-583-2013, 2013.

Favier, V., Krinner, G., Amory, C., Gallée, H., Beaumet, J., and Agosta, C.: Antarctica-Regional Climate and Surface Mass Budget, Curr. Clim. Change Rep., 3, 303-315, 2017.

Fernandoy, F., Meyer, H., and Tonelli, M.: Stable water isotopes of precipitation and firn cores from the northern Antarctic Peninsula region as a proxy for climate reconstruction, The Cryosphere, 6 , 313-330, https://doi.org/10.5194/tc-6-313-2012, 2012.

Fernandoy, F., Tetzner, D., Meyer, H., Gacitúa, G., Hoffmann, K., Falk, U., Lambert, F., and MacDonell, S.: New insights into the use of stable water isotopes at the northern Antarctic Peninsula as a tool for regional climate studies, The Cryosphere, 12, 10691090, https://doi.org/10.5194/tc-12-1069-2018, 2018.

Frezzotti, M., Urbini, S., Proposito, M., Scarchilli, C., and Gandolfi, S.: Spatial and temporal variability of surface mass balance near Talos Dome, East Antarctica, J. Geophys. Res.-Earth Surf., 112, $1-15,2007$.

Fujita, K. and Abe, O.: Stable isotopes in daily precipitation at Dome Fuji, East Antarctica, Geophys. Res. Lett., 33, 1-4, https://doi.org/10.1029/2006GL026936, 2006.

Gallée, H., Trouvilliez, A., Agosta, C., Genthon, C., Favier, V., and Naaim-Bouvet, F.: Transport of snow by the wind: A comparison between observations in Adélie Land, Antarctica, and simulations made with the regional climate model MAR, Bound.-Lay. Meteorol., 146, 133-147, 2013.

Genthon, C., Six, D., Favier, V., Lazzara, M., and Keller, L.: Atmospheric temperature measurement biases on the Antarctic plateau, J. Atmos. Ocean. Technol., 28, 1598-1605, 2011.

Ginot, P., Stampfli, F., Stampfli, D., Schwikowski, M., and Gaggeler, H.: FELICS, a new ice core drilling system for highaltitude glaciers, Memoirs of National Institute of Polar Research,Special issue, 56, 38-48, 2002.

Goursaud, S., Masson-Delmotte, V., Favier, V., Preunkert, S., Fily, M., Gallée, H., Jourdain, B., Legrand, M., Magand, O., Minster, B., and Werner, M.: A 60-year ice-core record of regional climate from Adélie Land, coastal Antarctica, The Cryosphere, 11, 343 362, https://doi.org/10.5194/tc-11-343-2017, 2017.

Goursaud, S., Masson-Delmotte, V., Favier, V., Orsi, A., and Werner, M.: Water stable isotope spatio-temporal variability in Antarctica in 1960-2013: observations and simulations from the ECHAM5-wiso atmospheric general circulation model, Clim. Past, 14, 923-946, https://doi.org/10.5194/cp-14923-2018, 2018a.

Goursaud, S., Masson-Delmotte, V., Favier, V., Preunkert, S., Legrand, M. R., and Minster, B.: The TA192A water stable isotope and chemical firn core records, Adélie Land, Antarctica, PANGAEA, https://doi.org/10.1594/PANGAEA.896623, Data set, in review, 2018b.

Graf, W., Oerter, H., Reinwarth, O., Stichler, W., Wilhelms, F., Miller, H., and Mulvaney, R.: Stable-isotope records from Dronning Maud Land, Antarctica, Ann. Glaciol., 35, 195-201, 2002.

Grazioli, J., Genthon, C., Boudevillain, B., Duran-Alarcon, C., Del Guasta, M., Madeleine, J.-B., and Berne, A.: Measurements of precipitation in Dumont d'Urville, Adélie Land, East Antarctica,
The Cryosphere, 11, 1797-1811, https://doi.org/10.5194/tc-111797-2017, 2017a.

Grazioli, J., Madeleine, J.-B., Gallée, H., Forbes, R. M., Genthon, C., Krinner, G., and Berne, A.: Katabatic winds diminish precipitation contribution to the Antarctic ice mass balance, P. Natl. Acad. Sci. USA, 114, 10858-10863, 2017b.

Henley, B. J., Gergis, J., Karoly, D. J., Power, S., Kennedy, J., and Folland, C. K.: A tripole index for the interdecadal Pacific oscillation, Clim. Dynam., 45, 3077-3090, 2015.

Isaksson, E. and Karlén, W.: Spatial and temporal patterns in snow accumulation, western Dronning Maud Land, Antarctica, J. Glaciol., 40, 399-409, 1994.

Johnsen, S.: Stable isotope homogenization of polar firn and ice, Isotopes and impurities in snow and ice, Phys. Ice Core Rec., 118, 210-219, 1977.

Johnsen, S. J., Clausen, H. B., Cuffey, K. M., Hoffmann, G., Schwander, J., and Creyts, T.: Diffusion of stable isotopes in polar firn and ice: the isotope effect in firn diffusion, Phys. Ice Core Rec., 121-140, 2000.

Jones, J. M., Gille, S. T., Goosse, H., Abram, N. J., Canziani, P. O., Charman, D. J., Clem, K. R., Crosta, X., De Lavergne, C., and Eisenman, I.: Assessing recent trends in high-latitude Southern Hemisphere surface climate, Nat. Clim. Change, 6, 917-926, 2016.

Jones, T., Cuffey, K., White, J., Steig, E., Buizert, C., Markle, B., McConnell, J., and Sigl, M.: Water isotope diffusion in the WAIS Divide ice core during the Holocene and last glacial, J. Geophys. Res.-Earth Surf., 122, 290-309, 2017.

Jourdain, B. and Legrand, M.: Seasonal variations of atmospheric dimethylsulfide, dimethylsulfoxide, sulfur dioxide, methanesulfonate, and non-sea-salt sulfate aerosols at Dumont d'Urville (coastal Antarctica) (December 1998 to July 1999), J. Geophys. Res.-Atmos., 106, 14391-14408, 2001.

Jourdain, B. and Legrand, M.: Year-round records of bulk and sizesegregated aerosol composition and $\mathrm{HCl}$ and $\mathrm{HNO} 3$ levels in the Dumont d'Urville (coastal Antarctica) atmosphere: Implications for sea-salt aerosol fractionation in the winter and summer, J. Geophys. Res.-Atmos., 107, 1-13, 2002.

Jouzel, J., Lorius, C., Petit, J., Genthon, C., Barkov, N., Kotlyakov, V., and Petrov, V.: Vostok ice core: a continuous isotope temperature record over the last climatic cycle (160,000 years), Nature, 329, 403-408, 1987.

Jouzel, J., Alley, R. B., Cuffey, K., Dansgaard, W., Grootes, P., Hoffmann, G., Johnsen, S. J., Koster, R., Peel, D., and Shuman, C.: Validity of the temperature reconstruction from water isotopes in ice cores, J. Geophys. Res.-Oceans, 102, 26471-26487, 1997.

Jouzel, J., Delaygue, G., Landais, A., Masson-Delmotte, V., Risi, C., and Vimeux, F.: Water isotopes as tools to document oceanic sources of precipitation, Water Resour. Res., 49, 7469-7486, 2013.

König-Langlo, G., King, J., and Pettré, P.: Climatology of the three coastal Antarctic stations Dumont d'Urville, Neumayer, and Halley, J. Geophys. Res.-Atmos., 103, 10935-10946, 1998.

Krinner, G., Guicherd, B., Ox, K., Genthon, C., and Magand, O.: Influence of oceanic boundary conditions in simulations of Antarctic climate and surface mass balance change during the coming century, J. Climate, 21, 938-962, 2008.

Kurita, N., Hirasawa, N., Koga, S., Matsushita, J., Steen-Larsen, H. C., Masson-Delmotte, V., and Fujiyoshi, Y.: Influence of large- 
scale atmospheric circulation on marine air intrusion toward the East Antarctic coast, Geophys. Res. Lett., 43, 9298-9305, 2016.

Küttel, M., Steig, E. J., Ding, Q., Monaghan, A. J., and Battisti, D. S.: Seasonal climate information preserved in West Antarctic ice core water isotopes: relationships to temperature, large-scale circulation, and sea ice, Clim. Dynam., 39, 1841-1857, 2012.

Landais, A., Ekaykin, A., Barkan, E., Winkler, R., and Luz, B.: Seasonal variations of ${ }^{17} \mathrm{O}$-excess and $d$-excess in snow precipitation at Vostok station, East Antarctica, J. Glaciol., 58, 725-733, 2012.

Legrand, M., Yang, X., Preunkert, S., and Theys, N.: Year-round records of sea salt, gaseous, and particulate inorganic bromine in the atmospheric boundary layer at coastal (Dumont d'Urville) and central (Concordia) East Antarctic sites, J. Geophys. Res.Atmos., 121, 997-1023, 2016.

Legrand, M., Preunkert, S., Weller, R., Zipf, L., Elsässer, C., Merchel, S., Rugel, G., and Wagenbach, D.: Year-round record of bulk and size-segregated aerosol composition in central Antarctica (Concordia site) - Part 2: Biogenic sulfur (sulfate and methanesulfonate) aerosol, Atmos. Chem. Phys., 17, 1405514073, https://doi.org/10.5194/acp-17-14055-2017, 2017a.

Legrand, M., Preunkert, S., Wolff, E., Weller, R., Jourdain, B., and Wagenbach, D.: Year-round records of bulk and sizesegregated aerosol composition in central Antarctica (Concordia site) - Part 1: Fractionation of sea-salt particles, Atmos. Chem. Phys., 17, 14039-14054, https://doi.org/10.5194/acp-17-140392017, 2017b.

Liu, H., Jezek, K., Li, B., and Zhao, Z.: Radarsat Antarctic Mapping Project digital elevation model version 2, Radarsat Antarctic Mapping Project digital elevation model version 2, Boulder, Colorado USA: National Snow and Ice Data Center, Digital media, 2001.

Markle, B., Bertler, N., Sinclair, K., and Sneed, S.: Synoptic variability in the Ross Sea region, Antarctica, as seen from backtrajectory modeling and ice core analysis, J. Geophys. Res.Atmos., 117, 1-17, 2012.

Marshall, G. J.: Trends in the Southern Annular Mode from observations and reanalyses, J. Climate, 16, 4134-4143, 2003.

Massom, R., Reid, P., Stammerjohn, S., Raymond, B., Fraser, A., and Ushio, S.: Change and variability in East Antarctic sea ice seasonality, 1979/80-2009/10, PloS one, 8, e64756, https://doi.org/10.1371/journal.pone.0064756, 2013.

Masson-Delmotte, V., Delmotte, M., Morgan, V., Etheridge, D., Van Ommen, T., Tartarin, S., and Hoffmann, G.: Recent southern Indian Ocean climate variability inferred from a Law Dome ice core: New insights for the interpretation of coastal Antarctic isotopic records, Clim. Dynam., 21, 153-166, 2003.

Masson-Delmotte, V., Hou, S., Ekaykin, A., Jouzel, J., Aristarain, A., Bernardo, R., Bromwich, D., Cattani, O., Delmotte, M., Falourd, S., Frezzotti, M., Gallée, H., Genoni, L., Isaksson, E., Landais, A., Helsen, M., Hoffmann, G., Lopez, J., Morgan, V., Motoyama, H., Noone, D., Oerter, H., Petit, J., Royer, A., Uemera, R., Schmidt, G., Schlosser, E., Simões, J., Steig, E., Stenni, B., Stievenard, M., van den Broeke, M., van de Wal, R., van de Berg, W., Vimeux, F., and White, J.: A review of Antarctic surface snow isotopic composition: Observations, atmospheric circulation, and isotopic modeling, J. Climate, 21, 3359-3387, 2008.
Merlivat, L. and Jouzel, J.: Global climatic interpretation of the deuterium-oxygen 18 relationship for precipitation, J. Geophys. Res.-Oceans, 84, 5029-5033, https://doi.org/10.1029/JC084iC08p05029, 1979.

Minikin, A., Legrand, M., Hall, J., Wagenbach, D., Kleefeld, C., Wolff, E., Pasteur, E. C., and Ducroz, F.: Sulfur-containing species (sulfate and methanesulfonate) in coastal Antarctic aerosol and precipitation, J. Geophys. Res.-Atmos., 103, 1097510990, 1998.

Morgan, V. I., Wookey, C., Li, J., Van Ommen, T., Skinner, W., and Fitzpatrick, M.: Site information and initial results from deep ice drilling on Law Dome, Antarctica, J. Glaciol., 43, 3-10, 1997.

Mulvaney, R., Oerter, H., Peel, D. A., Graf, W., Arrowsmith, C., Pasteur, E. C., Knight, B., Littot, G. C., and Miners, W. D.: 1000 year ice-core records from Berkner Island, Antarctica, Ann. Glaciol., 35, 45-51, 2002.

Naithani, J., Gallée, H., and Schayes, G.: Marine air intrusion into the Adelie Land sector of East Antarctica: A study using the regional climate model (MAR), J. Geophys. Res.-Atmos., 107, ACL6-1-ACL6-16, https://doi.org/10.1029/2000JD000274, 2002.

Nicolas, J. P. and Bromwich, D. H.: New Reconstruction of Antarctic Near-Surface Temperatures: Multidecadal Trends and Reliability of Global Reanalyses, J. Climate, 27, 8070-8093, 2014.

Noone, D.: The influence of midlatitude and tropical overturning circulation on the isotopic composition of atmospheric water vapor and Antarctic precipitation, J. Geophys. Res.-Atmos., 113, $1-13,2008$.

Noone, D. and Simmonds, I.: Associations between $\delta^{18} \mathrm{O}$ of water and climate parameters in a simulation of atmospheric circulation for 1979-95, J. Climate, 15, 3150-3169, 2002.

Noone, D. and Simmonds, I.: Sea ice control of water isotope transport to Antarctica and implications for ice core interpretation, J. Geophys. Res.-Atmos., 109, 1-13, 2004.

Périard, C. and Pettré, P.: Some aspects of the climatology of dumont D'Irville, adélie land, Antarctica, Int. J. Climatol., 13, 313328, 1993.

Petit, J., White, J., Young, N., Jouzel, J., and Korotkevich, Y. S.: Deuterium excess in recent Antarctic snow, J. Geophys. Res.Atmos., 96, 5113-5122, 1991.

Pettré, P. and Périard, C.: Aspects du climat de Dumont-d'Urviller et de l'Antarctique, Rubrique: Climatologie, 13, 55-62, 1996.

Pettré, P., Pinglot, J., Pourchet, M., and Reynaud, L.: Accumulation distribution in Terre Adélie, Antarctica: effect of meteorological parameters, J. Glaciol., 32, 486-500, 1986.

Pfahl, S. and Sodemann, H.: What controls deuterium excess in global precipitation?, Clim. Past, 10, 771-781, https://doi.org/10.5194/cp-10-771-2014, 2014.

Preunkert, S., Jourdain, B., Legrand, M., Udisti, R., Becagli, S., and Cerri, O.: Seasonality of sulfur species (dimethyl sulfide, sulfate, and methanesulfonate) in Antarctica: Inland versus coastal regions, J. Geophys. Res.-Atmos., 113, 1-10, 2008.

Rahaman, W., Thamban, M., and Laluraj, C.: Twentieth-century sea ice variability in the Weddell Sea and its effect on moisture transport: Evidence from a coastal East Antarctic ice core record, The Holocene, 26, 338-349, 2016.

Ritter, F., Steen-Larsen, H. C., Werner, M., Masson-Delmotte, V., Orsi, A., Behrens, M., Birnbaum, G., Freitag, J., Risi, C., and Kipfstuhl, S.: Isotopic exchange on the diurnal scale be- 
tween near-surface snow and lower atmospheric water vapor at Kohnen station, East Antarctica, The Cryosphere, 10, 16471663, https://doi.org/10.5194/tc-10-1647-2016, 2016.

Roeckner, E., Bäuml, G., Bonaventura, L., Brokopf, R., Esch, M., Giorgetta, M., Hagemann, S., Kirchner, I., Kornblueh, L., and Manzini, E.: The atmospheric general circulation model ECHAM 5, PART I: Model description, 2003.

Rozanski, K., Araguás-Araguás, L., and Gonfiantini, R.: Isotopic patterns in modern global precipitation, Clim. Change Conti. Isotop. Rec., 78, 1-36, 1993.

Schlosser, E., Reijmer, C., Oerter, H., and Graf, W.: The influence of precipitation origin on the $\delta^{18} \mathrm{O}-T$ relationship at Neumayer station, Ekstrmisen, Antarctica, Ann. Glaciol., 39, 41-48, 2004.

Schlosser, E., Oerter, H., Masson-Delmotte, V., and Reijmer, C.: Atmospheric influence on the deuterium excess signal in polar firn: implications for ice-core interpretation, J. Glaciol., 54, $117-$ 124,2008

Schlosser, E., Dittmann, A., Stenni, B., Powers, J. G., Manning, K. W., Masson-Delmotte, V., Valt, M., Cagnati, A., Grigioni, P., and Scarchilli, C.: The influence of the synoptic regime on stable water isotopes in precipitation at Dome C, East Antarctica, The Cryosphere, 11, 2345-2361, https://doi.org/10.5194/tc-11-23452017, 2017.

Sime, L. C., Tindall, J. C., Wolff, E. W., Connolley, W. M., and Valdes, P. J.: Antarctic isotopic thermometer during $\mathrm{C} \mathrm{CO}_{2}$ forced warming event, J. Geophys. Res.-Atmos., 113, 1-16, 2008.

Simmons, A., Jones, P., da Costa Bechtold, V., Beljaars, A., Kållberg, P., Saarinen, S., Uppala, S., Viterbo, P., and Wedi, N.: Comparison of trends and low-frequency variability in CRU, ERA-40, and NCEP/NCAR analyses of surface air temperature, J. Geophys. Res.-Atmos., 109, 1-18, 2004.

Sinclair, K., Bertler, N., and Trompetter, W.: Synoptic controls on precipitation pathways and snow delivery to high-accumulation ice core sites in the Ross Sea region, Antarctica, J. Geophys. Res.-Atmos., 115, 1-11, 2010.

Sinclair, K. E., Bertler, N. A., Bowen, M. M., and Arrigo, K. R.: Twentieth century sea-ice trends in the Ross Sea from a high-resolution, coastal ice-core record, Geophys. Res. Lett., 41, 3510-3516, 2014.

Sodemann, H. and Stohl, A.: Asymmetries in the moisture origin of Antarctic precipitation, Geophys. Res. Lett., 36, 1-5, 2009.

Steen-Larsen, H., Risi, C., Werner, M., Yoshimura, K., and MassonDelmotte, V.: Evaluating the skills of isotope-enabled general circulation models against in situ atmospheric water vapor isotope observations, J. Geophys. Res.-Atmos., 122, 246-263, 2017.

Steig, E. J., Ding, Q., White, J. W., Küttel, M., Rupper, S. B., Neumann, T. A., Neff, P. D., Gallant, A. J., Mayewski, P. A., and Taylor, K. C.: Recent climate and ice-sheet changes in West Antarctica compared with the past 2,000 years, Nat. Geosci., 6, 372375, 2013.

Stein, A., Draxler, R. R., Rolph, G. D., Stunder, B. J., Cohen, M., and Ngan, F.: NOAA's HYSPLIT atmospheric transport and dispersion modeling system, B. Am. Meteorol. Soc., 96, 20592077, 2015.

Stenni, B., Masson-Delmotte, V., Johnsen, S., Jouzel, J., Longinelli, A., Monnin, E., Röthlisberger, R., and Selmo, E.: An oceanic cold reversal during the last deglaciation, Science, 293, 20742077, 2001.
Stenni, B., Scarchilli, C., Masson-Delmotte, V., Schlosser, E., Ciardini, V., Dreossi, G., Grigioni, P., Bonazza, M., Cagnati, A., Karlicek, D., Risi, C., Udisti, R., and Valt, M.: Threeyear monitoring of stable isotopes of precipitation at Concordia Station, East Antarctica, The Cryosphere, 10, 2415-2428, https://doi.org/10.5194/tc-10-2415-2016, 2016.

Stenni, B., Curran, M. A. J., Abram, N. J., Orsi, A., Goursaud, S., Masson-Delmotte, V., Neukom, R., Goosse, H., Divine, D., van Ommen, T., Steig, E. J., Dixon, D. A., Thomas, E. R., Bertler, N. A. N., Isaksson, E., Ekaykin, A., Werner, M., and Frezzotti, M.: Antarctic climate variability on regional and continental scales over the last 2000 years, Clim. Past, 13, 1609-1634, https://doi.org/10.5194/cp-13-1609-2017, 2017.

Thomas, E. R., Bracegirdle, T. J., Turner, J., and Wolff, E. W.: A 308 year record of climate variability in West Antarctica, Geophys. Res. Lett., 40, 5492-5496, 2013.

Thomas, E. R., van Wessem, J. M., Roberts, J., Isaksson, E., Schlosser, E., Fudge, T. J., Vallelonga, P., Medley, B., Lenaerts, J., Bertler, N., van den Broeke, M. R., Dixon, D. A., Frezzotti, M., Stenni, B., Curran, M., and Ekaykin, A. A.: Regional Antarctic snow accumulation over the past 1000 years, Clim. Past, 13, 1491-1513, https://doi.org/10.5194/cp-13-1491-2017, 2017.

Touzeau, A., Landais, A., Stenni, B., Uemura, R., Fukui, K., Fujita, S., Guilbaud, S., Ekaykin, A., Casado, M., Barkan, E., Luz, B., Magand, O., Teste, G., Le Meur, E., Baroni, M., Savarino, J., Bourgeois, I., and Risi, C.: Acquisition of isotopic composition for surface snow in East Antarctica and the links to climatic parameters, The Cryosphere, 10, 837-852, https://doi.org/10.5194/tc-10-837-2016, 2016.

Turner, J., Colwell, S. R., Marshall, G. J., Lachlan-Cope, T. A., Carleton, A. M., Jones, P. D., Lagun, V., Reid, P. A., and Iagovkina, S.: The SCAR READER project: toward a high-quality database of mean Antarctic meteorological observations, J. Climate, 17, 2890-2898, 2004.

Turner, J., Lu, H., White, I., King, J. C., Phillips, T., Hosking, J. S., Bracegirdle, T. J., Marshall, G. J., Mulvaney, R., and Deb, P.: Absence of 21st century warming on Antarctic Peninsula consistent with natural variability, Nature, 535, 411-415, 2016.

Uemura, R., Matsui, Y., Yoshimura, K., Motoyama, H., and Yoshida, N.: Evidence of deuterium excess in water vapor as an indicator of ocean surface conditions, J. Geophys. Res.-Atmos., 113, 1-10, 2008.

van der Wel, G., Fischer, H., Oerter, H., Meyer, H., and Meijer, H. A. J.: Estimation and calibration of the water isotope differential diffusion length in ice core records, The Cryosphere, 9, 16011616, https://doi.org/10.5194/tc-9-1601-2015, 2015.

Vega, C. P., Schlosser, E., Divine, D. V., Kohler, J., Martma, T., Eichler, A., Schwikowski, M., and Isaksson, E.: Surface mass balance and water stable isotopes derived from firn cores on three ice rises, Fimbul Ice Shelf, Antarctica, The Cryosphere, 10, 2763-2777, https://doi.org/10.5194/tc-10-2763-2016, 2016.

Verfaillie, D., Fily, M., Le Meur, E., Magand, O., Jourdain, B., Arnaud, L., and Favier, V.: Snow accumulation variability derived from radar and firn core data along a $600 \mathrm{~km}$ transect in Adelie Land, East Antarctic plateau, The Cryosphere, 6, 1345-1358, https://doi.org/10.5194/tc-6-1345-2012, 2012.

Vimeux, F., Masson, V., Jouzel, J., Stievenard, M., and Petit, J.: Glacial-interglacial changes in ocean surface conditions in the Southern Hemisphere, Nature, 398, 410-413, 1999. 
Vimeux, F., Masson, V., Delaygue, G., Jouzel, J., Petit, J., and Stievenard, M.: A 420,000 year deuterium excess record from East Antarctica: Information on past changes in the origin of precipitation at Vostok, J. Geophys. Res.-Atmos., 106, 3186331873, 2001.

Werner, M., Langebroek, P. M., Carlsen, T., Herold, M., and Lohmann, G.: Stable water isotopes in the ECHAM5 general circulation model: Toward high-resolution isotope modeling on a global scale, J. Geophys. Res.-Atmos., 116, D15109, https://doi.org/10.1029/2011JD015681, 2011.

Winstrup, M., Vallelonga, P., Kjær, H. A., Fudge, T. J., Lee, J. E., Riis, M. H., Edwards, R., Bertler, N. A. N., Blunier, T., Brook, E. J., Buizert, C., Ciobanu, G., Conway, H., Dahl-Jensen, D., Ellis, A., Emanuelsson, B. D., Keller, E. D., Kurbatov, A., Mayewski, P., Neff, P. D., Pyne, R., Simonsen, M. F., Svensson, A., Tuohy, A., Waddington, E., and Wheatley, S.: A 2700year annual timescale and accumulation history for an ice core from Roosevelt Island, West Antarctica, Clim. Past Discuss., https://doi.org/10.5194/cp-2017-101, in review, 2017.
Yao, T., Petit, J., Jouzel, J., Lorius, C., and Duval, P.: Climatic record from an ice margin area in East Antarctica, Ann. Glaciol., 14, 323-327, 1990. 